\title{
Building Future Scenarios Governance, Land Use, and Carbon Management at the Landscape Scale
}

Ashwin Ravikumar, Jazmin Gonzales Tovar, Laura Kowler, Anne M. Larson

Global Comparative Study on REDD+ Multilevel Governance and Carbon Management at the Landscape Scale
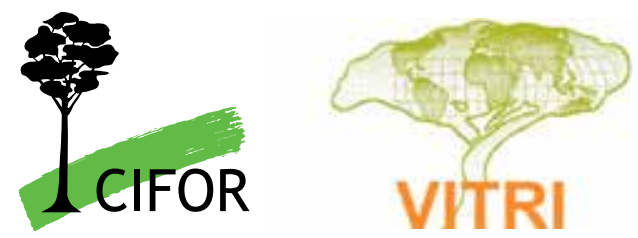


\section{WORKSHOP FACILITATION GUIDE}

\section{Building Future Scenarios Governance, Land Use, and Carbon Management at the Landscape Scale}

Ashwin Ravikumar, Jazmin Gonzales Tovar, Laura Kowler, Anne M. Larson

Global Comparative Study on REDD+

Multilevel Governance and Carbon

Management at the Landscape Scale

July 2014 
(c) 2014 Center for International Forestry Research

(c) (1) Content in this publication is licensed under a Creative Commons Attribution 4.0 International (CC BY 4.0), http://creativecommons.org/licenses/by/4.0/

Ravikumar A, Gonzales TJ, Kowler L and Larson AM. 2014. Building future scenarios: Governance, land use and carbon management at the landscape scale. Workshop facilitation guide. Bogor, Indonesia: CIFOR.

Photo credits: Jazmin Gonzales Tovar, Laura Kowler, and Markku Larjavaara

CIFOR

J. CIFOR, Situ Gede

Bogor Barat 16115

Indonesia

$T+62(251) 8622-622$

F +62 (251) 8622-100

E cifor@cgiar.org

\section{cifor.org}

We would like to thank all donors who supported this research through their contributions to the CGIAR Fund. For a list of Fund donors please see: https://www.cgiarfund.org/FundDonors

Any views expressed in this publication are those of the authors. They do not necessarily represent the views of CIFOR, the editors, the authors' institutions, the financial sponsors or the reviewers. 


\section{Table of contents}

$\begin{array}{ll}\text { ACKNOWLEDGMENTS } & 1\end{array}$

INTRODUCTION AND OBJECTIVES 2

$\begin{array}{ll}\text { PARTICIPANTS } & 3\end{array}$

$\begin{array}{ll}\text { STRUCTURE } & 4\end{array}$

FRAMEWORK AND METHODOLOGY 5

DAY 1 FUTURE SCENARIOS OF LAND USE 7

1 Welcome, Presentation of the Agenda, and Introduction of

2 Timeline and History - "Journey to the Past" 10

3 Identifying factors of change 12

4 Selecting the most important and uncertain factors of change $\quad 14$

5 Constructing future scenarios of land use 16

6 End of day survey: linking scenarios and governance 24

DAY 2 CARBON MODELING AND GOVERNANCE MONITORING 26

1 Review of previous day 27

2 Carbon modeling: implications of future scenarios for carbon 28

3 Identifying strategies to reach a desirable future 29

4 Governance: Conceptual discussion 31

5 Monitoring and indicators of multilevel governance 33

6 Presentation of preliminary results from facilitation team study
(if relevant)

$\begin{array}{ll}7 \text { End of workshop survey } & 37\end{array}$

$\begin{array}{ll}\text { REFERENCES } & 39\end{array}$

$\begin{array}{ll}\text { ANNEX } & 40\end{array}$ 



\section{ACKNOWLEDGMENTS}

This workshop methodology was developed to fulfill particular objectives, described below. However, it was built on a foundation of previous work by several research organization, whose contributions were extremely valuable in developing this approach. In particular, we thank the CCAFS (Climate Change and Food Security) research program of the CGIAR (Consultative Group on International Agricultural Research) future scenarios team - specifically Joost Vervoot, Marieke Veeger and Deissy Martínez Barón - for providing substantial input and guidance on how to develop future scenarios in participatory workshops. Conversations, e-mail exchanges, and written inputs from Peter Cronkleton, Kristen Evans, and Victor Gutierrez were also helpful in compiling this methodology. We also want to thank the community of Hualquín Grande (Tarma, Peru) and regional officials from the province of Tarma, who kindly allowed us to experiment with an earlier version of the method with their participation. We want to thank as well the fellows from the Universidad Agraria La Molina, especially Ivonne Salazar Rodríguez and Enrique Adama Rojas, who contributed to planning and coordinating the pre-test in Tarma. Finally, this method was again refined after applying it in Madre de Dios and San Martin, Peru, with the support of the respective regional governments and workshop participants from the selected landscape in each province. 


\section{INTRODUCTION AND OBJECTIVES}

The workshops conducted using this guide were designed in order to meet several objectives associated with CIFOR's study of multilevel governance and carbon management at the landscape scale. Though we reviewed multiple existing facilitation methods, we did not find any that met our specific needs, which were based on

working with multiple stakeholders to develop future land use scenarios over detailed, bounded landscapes that encompass multiple actors and drivers of land use change.

The method we developed draws on the facilitation of landscape scenarios at smaller scales, combining experience from participatory action research and adaptive collaborative management at community level (Evans et al. 2006), and at much larger (multi-country) scales, adapting important concepts such as "factors of change" from the program on Climate Change Agriculture and Food Security (CCAFS) (Veeger, pers comm.; http://ccafs.cgiar.org/scenarios), and the methodology "landscape simulation for participatory land use planning" developed by Jeremy Bourgoin and Jean-Christophe Castella. ${ }^{1}$ The resulting method presented here is particularly useful for landscapes of 50,000 to 500,000 hectares - large enough to comprise multiple drivers and actors, but small enough to build on concrete knowledge of the geographical location. ${ }^{2}$ An accurate current land use map is an essential part of the exercise. ${ }^{3}$

\footnotetext{
1 We also incorporated some ideas from a methodology that links land use with zoning using a landscape approach (Bourgoin and Castella 2011).

2 The geographical focus of this workshop is the "landscape." For the purposes of this workshop, a "landscape" is treated as a geographically defined area with diverse land uses, where actors from multiple levels and sectors have an interest in and/ or influence over land use. In principle, the methodology can be adapted for landscapes of other sizes.

3 See Annex on workshop materials.
}

In this guide, the elaboration of alternative future scenarios is followed by the application of a simplified tool to model the carbon emissions patterns and outcomes of each option; this tool will be provided separately on the project web site and does not necessarily need to be included in the workshop activities. Finally, the workshop concludes with a discussion of pathways for reaching desirable scenarios, including of multilevel governance and the development of criteria and indicators for change. Any part of the methods can be adapted for particular needs.

\section{Overall objective:}

Develop plausible future scenarios of land use, calculate the carbon emissions implications of these distinct scenarios, and discuss strategies and activities for moving towards the desirable scenario(s).

\section{Specific Objectives:}

- Examine past land uses and change over time

- Develop future scenarios of land use at the landscape scale using participatory approaches

- Apply a simple carbon tool to calculate the carbon emissions implications of the distinct land use scenarios

- Identify key elements of multilevel governance and take steps towards the design and implementation of a governance monitoring tool

- Present preliminary results and observations from CIFOR's Global Comparative Study on REDD+ 


\section{PARTICIPANTS}

Workshops should include participants that represent all levels and sectors that have an interest in, or influence over, the landscape. This should include representatives from the public and private sectors, non-governmental organizations (NGOs), and civil society as appropriate. In addition, actors from local, subnational, and national levels should be involved. Some key actors to consider are:

- National Government (key ministries or divisions)

- Sub-national government, such as region, department or province (key ministries and divisions)
- Local governments, such as district, province, county, or municipality depending on the administrative sub-division structure of the country

- Private firms

- NGOs

- Indigenous peoples' organizations

- Community-based organizations, authorities, and committees 


\section{STRUCTURE}

This workshop takes place over the course of two days:

- The first day is focused on developing future scenarios of land use, and several activities are utilized to accomplish this: a visioning exercise to encourage creative thinking and orient participants towards ideas of future scenarios, constructing a timeline of key events in the past, defining key "factors of change" that are likely to shape future scenarios, characterization of various scenarios based on these factors, development of scenario narratives, and finally mapping land use changes under the distinct scenarios.

- The second day is dedicated to presenting models of the carbon implications of the scenarios constructed during the first day, discussing multilevel governance, indicators and governance monitoring, and presenting preliminary results of related research.

The following graphic shows the organization of the workshop:
DAY ONE: FUTURE SCENARIOS
OF LAND USE

DAY TWO:

CARBON EMISSIONS AND MULTILEVEL GOVERNANCE
- Visioning and Discussion of land use in the landscape

- Trip to the past (timeline)

Defining factors of change for land use

Constructing future scenarios of land use

Modeling the carbon emissions implications of the future scenarios: approach and preliminary results

Multilevel Governance:

- Elements of multilevel governance

- Governance monitoring and indicators

- Preliminary results and observations from research on multilevel governance 


\section{FRAMEWORK AND METHODOLOGY}

This workshop methodology is based on the construction of "future scenarios" of land use. Future scenarios are not predictions but rather hypothetical futures that could plausibly occur. Taking into account current and past drivers of change, and key existing uncertainties, diverse future scenarios are developed through narratives, images, statistics, and/or maps. Future scenarios can be a useful planning tool, as they allow for consideration of complexity and future uncertainty, taking into account the diversity of factors that may influence planning and future outcomes.

The methodology focuses on a landscape, or geographically defined area with multiple land uses, where actors from diverse levels and sectors have an interest or influence. Decisionmaking about land use in the landscape is thus an inherently multilevel process, characterized by multilevel governance. Thus, this workshop aims to include all relevant actors for the specific landscape, from the local to national level, and also across relevant sectors.

The methodology for developing future scenarios involves the following activities:

\section{Voyage to the future - visioning (Optional ice breaker and brief introductory activity)}

In this activity, participants reflect individually on the characteristics that a desirable future landscape would have. They are asked to close their eyes and imagine a better future 30 years down the line, noting what they see, what changes have occurred, and how the world looks. The goal of this activity is to orient participants towards their expectations and the future thinking and to "get the creativity flowing." (This activity is not included in this guide.)

\section{Trip to the past - timeline of land use} change

The goal of this activity is to construct a participatory timeline of events over the past 20 years. The facilitators ask participants in plenary, to name key events that have shaped and changed land use in the landscape. Identifying what events have been critical in the past can inform the identification of factors of change that are likely to be key determinants of future scenarios in the following activity.

\section{Factors of change}

Keeping in mind the key events identified in the previous activity, and remembering the aspects of a desirable future that were shared in the visioning exercise, participants work in "thematic groups" to identify about five key "factors of change" that are likely to shape land use in the future. For each factor of change, possible future states are discussed. Thematic groups include actors that work in similar levels or sectors, and should be decided based on who actually attends the workshop. In one workshop, for example, participants were divided into (a) national government, (b) regional government, (c) NGOs and civil society, and (d) indigenous peoples' representatives.

\section{Voting for the most important and uncertain factors}

After consolidating the factors of change to eliminate redundancy, each participant votes for the four factors that $\mathrm{s} /$ he finds most important, and the four factors that $\mathrm{s} /$ he finds most uncertain. Between four and six factors that are most important and also uncertain are selected. 


\section{Elaborating the future scenarios}

The workshop facilitators combine the different future states of the identified factors to present four distinct future scenarios, each with a different combination of factor states, for 30 years in the future. After receiving feedback from the participants and making any modifications, they divide into groups, this time randomly rather than thematically. Each group works on one of the scenarios, constructing a narrative that describes how the landscape reached this condition, using the states of factors of change presented for their scenario. After exploring the scenario deeply, they draw the physical land use changes that would exist under this scenario on a map.

\section{Presentation of the carbon tool}

The team presents the methodology behind the carbon calculator, and then presents the carbon emissions implications of the scenarios developed in the workshop.

\section{Strategies and steps}

After considering which scenarios are most desirable, the participants reflect individually on key steps that would need to be taken to get to the desirable future scenario. The participants then break into groups again to share their reflections, and develop a table answering the following questions for a number of those steps: (1) what needs to be done? (2) how will these things be done? And (3) who will have to do them? In addition, each group identifies barriers to these steps and how these barriers might be overcome.

\section{Multilevel governance: concept,} indicators, and monitoring

After a brainstorm where participants share what they understand the term "governance" to mean, the facilitators present definitions of "governance," "multilevel governance," "governance indicators," and "governance monitoring." Returning to the same groups from the previous activity, participants select one or two of the steps that they identified, and discuss (1) indicators of governance that should be measured (what should be measured?), (2) who should be in charge of monitoring these indicators?, (3) how should these indicators be monitored?, and (4) when should these indicators be monitored?

\section{Presentation of preliminary results and observations}

Finally, the team presents preliminary results and observations related to multilevel governance research conducted to date. 


\section{DAY 1}

\section{FUTURE SCENARIOS OF LAND USE}

\section{Proposed agenda}

\begin{tabular}{|c|c|}
\hline TIME & ACTIVITY \\
\hline 08:30-9:00 & Participant registration \\
\hline 09:00-09:30 & Opening remarks, workshop objectives and agenda \\
\hline 09:30-10:00 & Participant introductions and ice-breaker, including visioning optionally \\
\hline 10:00-11:00 & $\begin{array}{l}\text { "Trip to the Past:" Construct a timeline of key events in the past } 20 \text { years related to land use } \\
\text { change }\end{array}$ \\
\hline $11: 00-11: 15$ & Coffee Break \\
\hline $11: 15-12: 30$ & $\begin{array}{l}\text { Factors of change }(\mathrm{I}) \\
\text { Identify factors of change that influence land use and states that they may take on in } \\
\text { thematic groups }\end{array}$ \\
\hline $12: 30-13: 00$ & $\begin{array}{l}\text { Factors of change (II) } \\
\text { Select the factors of change that are most important, and also most uncertain }\end{array}$ \\
\hline $13: 00-14: 00$ & Lunch \\
\hline $14: 00-14: 30$ & $\begin{array}{l}\text { Presentation of the proposed scenarios, combinations of different states of the factors } \\
\text { selected determined by facilitation team }\end{array}$ \\
\hline $14: 30-16: 30$ & $\begin{array}{l}\text { Discussion of future scenarios of land use } \\
\text { Develop narratives for each scenario in mixed groups, and draw land use changes on maps } \\
\text { for each scenario }\end{array}$ \\
\hline $16: 30-16: 45$ & Break \\
\hline $16: 45-17: 30$ & $\begin{array}{l}\text { Present scenario narratives and maps } \\
\text { Each group presents their future scenario narrative and map }\end{array}$ \\
\hline $17: 30-18: 00$ & $\begin{array}{l}\text { Survey } \\
\text { Participants vote for which scenario they think is most desirable, and which is most probable. } \\
\text { They also provide feedback on their role in the governance of the landscape. }\end{array}$ \\
\hline
\end{tabular}




\section{Welcome, Presentation of the Agenda, and Introduction of Participants}

Approximate time and scope: 30 minutes, plenary

1. Introduce the workshop, and if applicable, the broader project that the facilitation team is undertaking that led to the workshop

2. Present the landscape that will be the focus of the workshop

3. Describe the agenda for the workshop, and mention any key ground rules for the workshop

4. Go around the room for participants to introduce themselves. An 'ice-breaker' game can be employed here optionally, and/or participants may be asked to briefly "envision" a better future and share their vision with the group to encourage creative thinking early in the workshop

\section{Facilitation notes:}

- Make the introduction brief and colloquial

- Show a map of the landscape that will be the focus of the workshop, and describe it quickly

- Lay out some ground rules for the workshop, noting that there is a diversity of actors present, and that there may be varied perspectives on the issues discussed. Point out that all participants' perspectives are valuable, and that this workshop should be as safe a space as possible for perspectives to be shared.

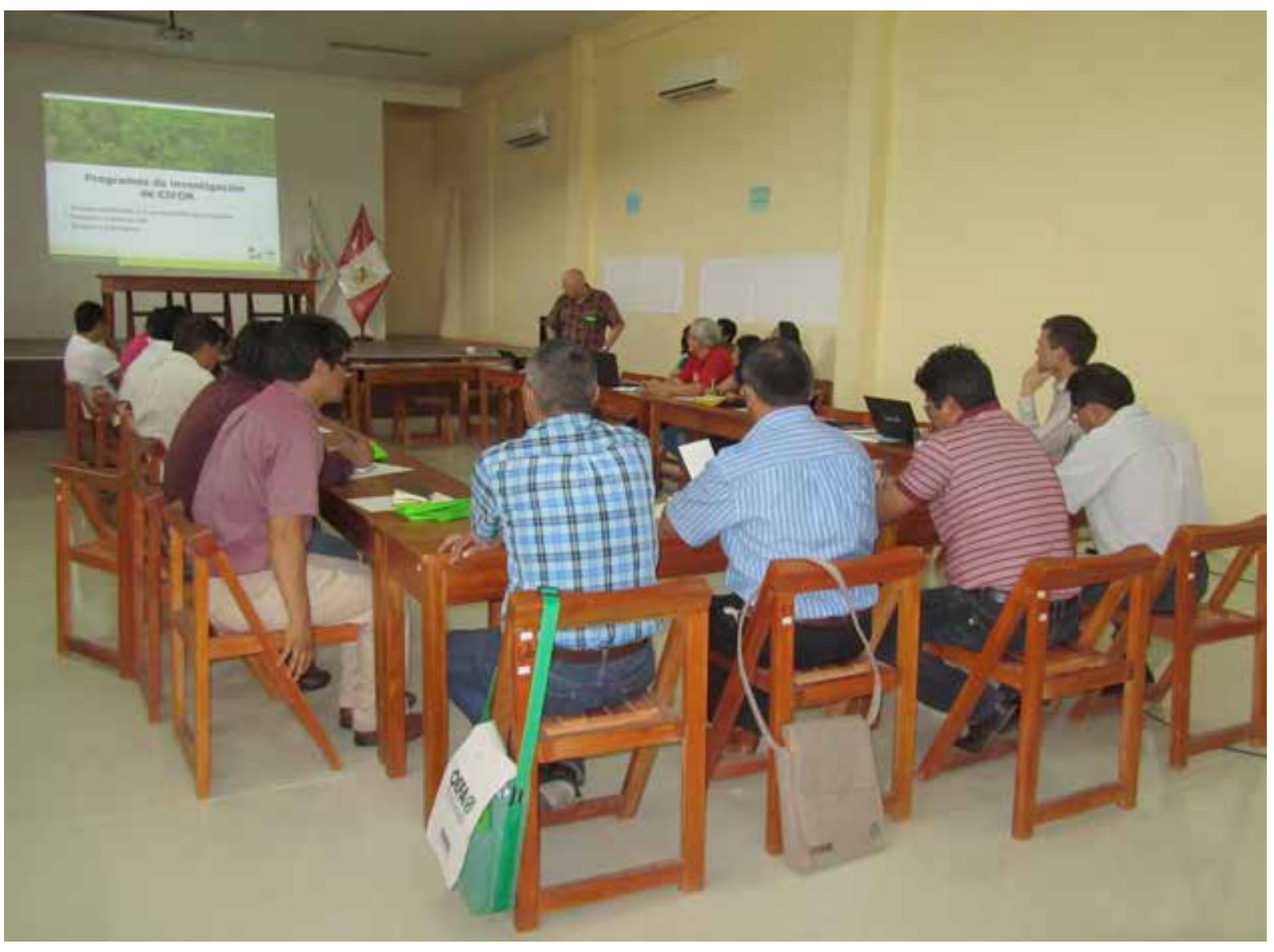



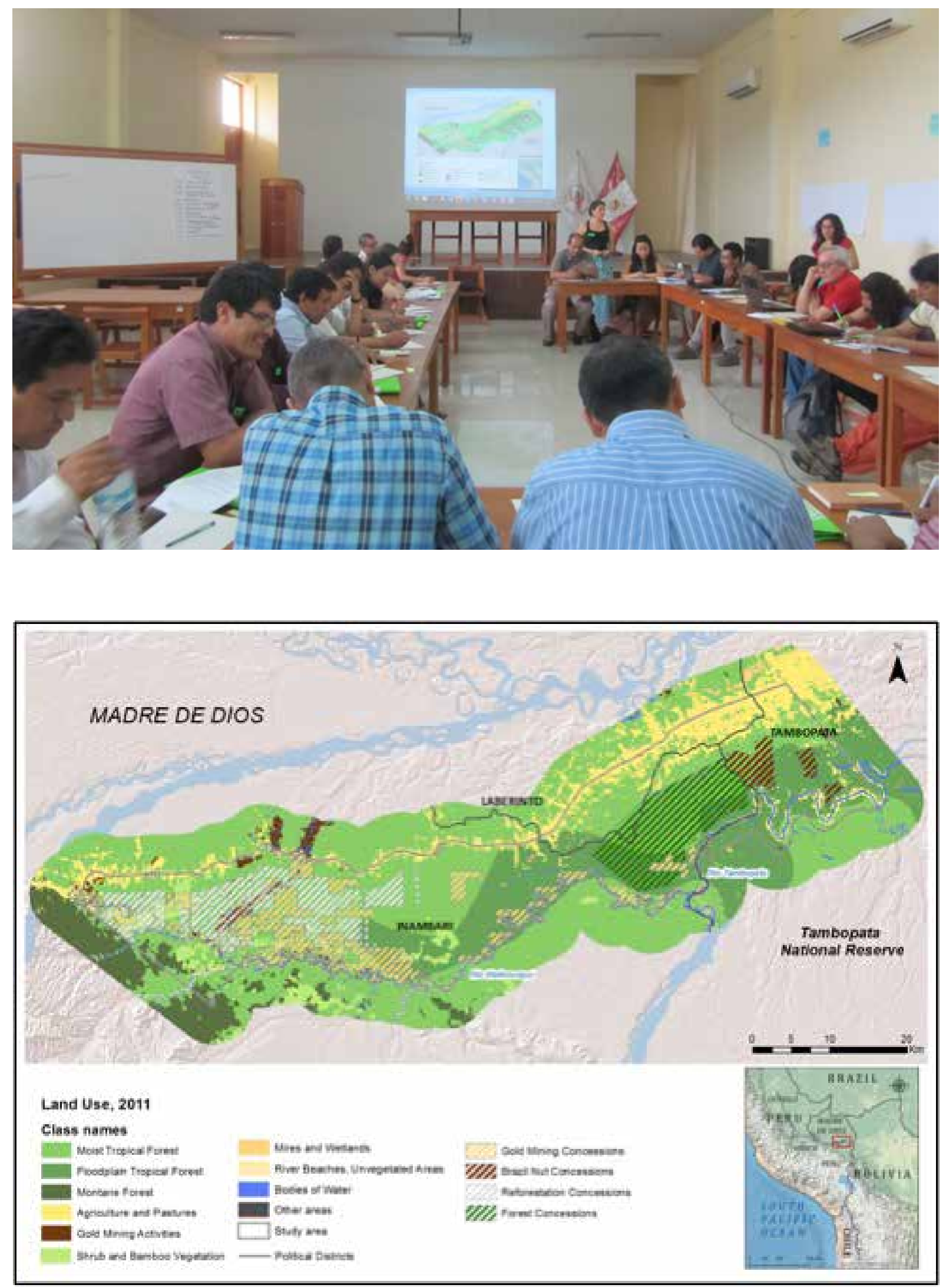

Example Map: The landscape around the Tambopata National Reserve (CIFOR-VITRI Workshop, Puerto Maldonado, Peru, May 2-3, 2014)

Source: Viikki Tropical Resources Institute - VITRI, University of Helsinki 


\title{
Timeline and History - "Journey to the Past"
}

\author{
Approximate time and scope: 30-60 minutes, plenary
}

\section{Objective}

The objective of this activity is to identify key moments, events, and eras in the past 2030 years that generated changes in land use that explain the landscape as it is today. In addition to bringing everyone to the same page on key historical events, this activity also serves to identify the types of events that have driven change historically, and by extension suggest what factors may shape land use changes in the future. This is important because the following activities aim to identify these "factors of change" that will be critical in the future.

This activity consists of the following steps:

1. Introduce the activity, explaining that the aim is to construct a timeline with the most crucial events and "moments" in the history of land use in the landscape

2. General questions aimed at the group might include:

\section{- "When did land use in this landscape change the most? What caused these changes?"}

- "What were the most critical events that led to changes in land use?"

- "Are there any activities that have expanded over time? What are these activities, and why did they change?"

- "Have there been any changes in policies that have affected land use?"

- "Have people migrated over the past 20 years? What has driven migrations and movements of people?"

3. It is best to have one facilitator ask these questions to participants, encouraging participants to provide new inputs that haven't already been mentioned. As one facilitator asks questions, another facilitator should write the responses down on large cards and this or a third person should stick them to the wall along the timeline.

4. Optionally, ask participants to identify three main "eras" of land use in the landscape based on the events that have been described. This is useful in understanding the overall trajectory of land use change in the past 20 years.

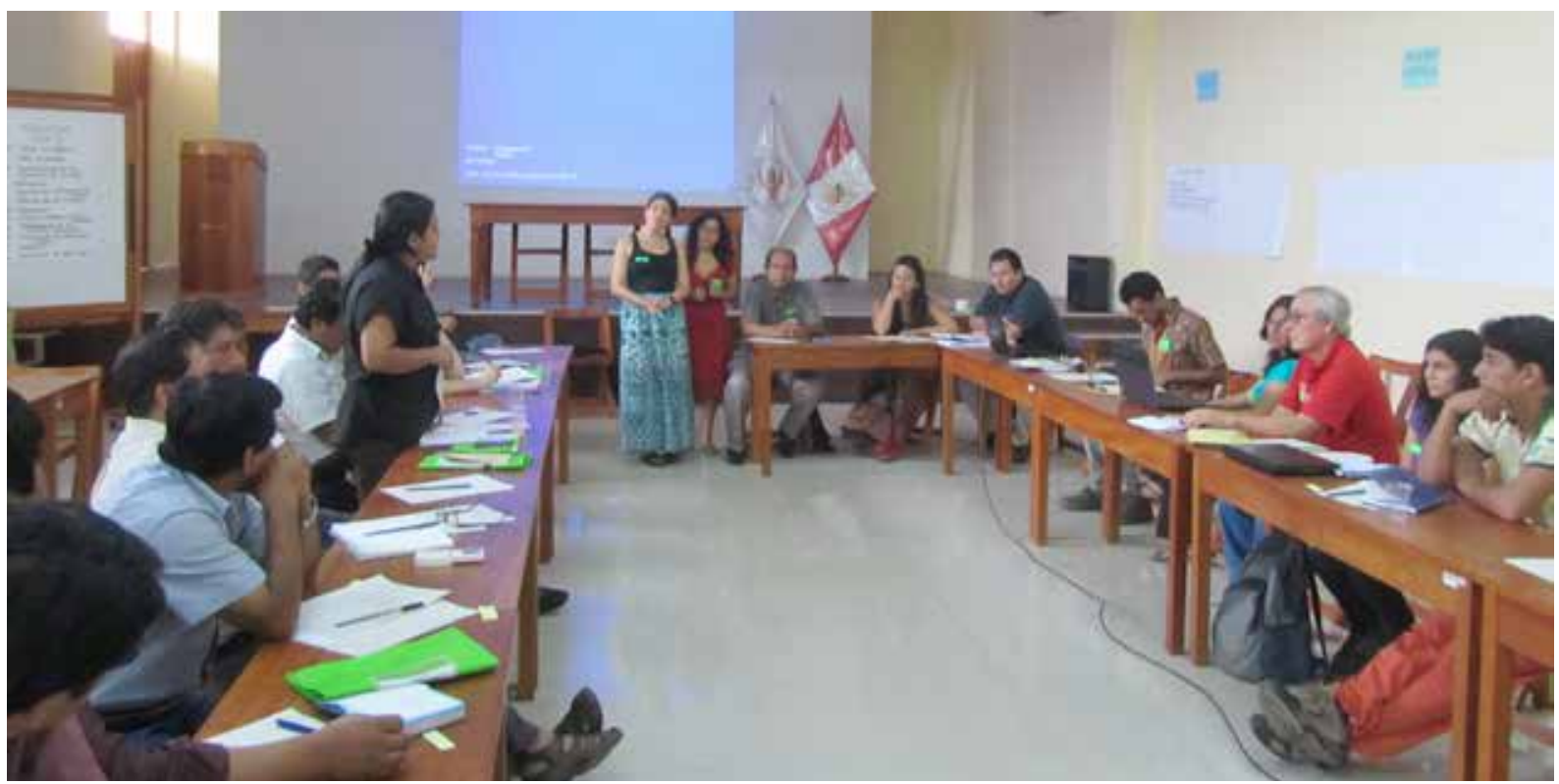




\section{Facilitation notes:}

- This activity requires strong facilitation. It is helpful to have three people to keep the pace moving.

- If respondents are focusing primarily or exclusively on one period of time within the 20-year period of interest, make sure to explicitly ask for events at other times. For example, if many events in the past 10 years are mentioned but none in the preceding 10 years, ask participants about what happened in the first 10 years of the 20-year period.

- If participants have trouble understanding the activity or the types of events that are being requested, additional prompts may be used. For example:

On population dynamics:

\section{- "When were the first land titles granted in the landscape, and why?"}

- "Has the population increased or decreased over time? What has caused migrations or population changes?"

\section{- "Have any roads been built or other changes in infrastructure occurred?"}

On the local economy:

\section{- "Did the main economic activity change at any time? Did certain crops become more common} and other crops become less common?"

- "Have any policies affected agriculture in the landscape?"

- "Has there been deforestation recently? Why?"

- If participants are providing responses that do not deal explicitly with land use, but rather the general history of the area, facilitators should remind participants to mention events and moments that affected land use in particular. Other aspects of history may be important to understand the context, but if time is short, the priority should be events with explicit consequences for land use.

- Fill out the entire timeline before requesting more details on individual events

\section{Variation/alternative approach:}

Facilitators give 1-2 cards to participants to write down a key event on each. Participants then explain their choices, and they or the facilitators stick the cards to the timeline on the Wall.

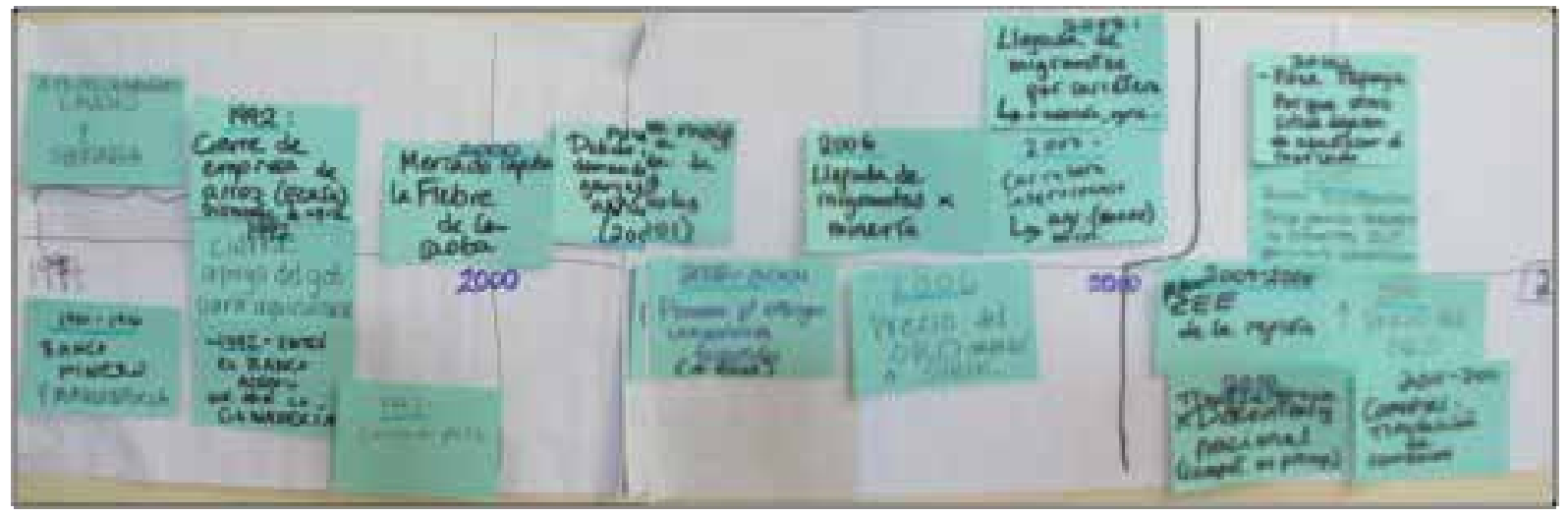




\section{Identifying factors of change}

Approximate time: 60-70 minutes, plenary, individual, and break-out groups

\section{Objective}

Keeping in mind the key events identified in the previous activity, participants work in groups to identify "factors of change" that are likely to influence land use in the future landscape. This component of the workshop methodology borrows heavily from the future scenarios approach developed by the CCAFS (Climate Change and Food Security) research program of CGIAR (Consultative Group on International Agricultural Research).

\section{Methodology - Part 1: Conceptual explanation in plenary ( $5 \mathrm{~min}$.)}

A member of the facilitation team should briefly explain what a "factor of change" is. This facilitator should highlight that factors of change are variable, and are likely to exert an influence on the landscape looking to the future. The facilitator can optionally cite an example from the timeline as a "factor" that affected land use in the past. For example, in the workshop in Madre de Dios, Peru, respondents cited both increased migration and the rising price of gold as having had an influence on land use change in the past. In the future, therefore, the price of gold may or may not be a factor of change.

Another key feature of "factors of change" is that they may take on multiple "states." The price of gold, for example, may be either "high," "low," or "in between." If framed in reference to how it changes, the price of gold may "rise," "fall," or "remain constant." Facilitators should explain this concept and ensure that all participants understand, prior to moving into individual work and then breakout groups.

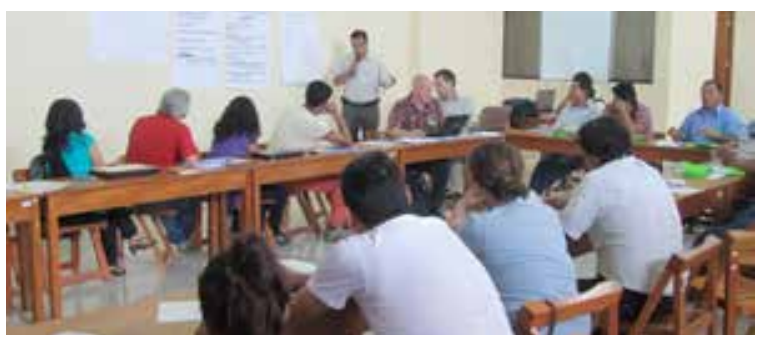

\section{Methodology - Part 2: Individual work (10 min.)}

1. Ask the participants:

- "What is causing land use change in the landscape? Considering what you know about the landscape, and what we've just discussed about its history, what are the main factors that are likely to be important going forward?"

- "What factors are likely to be important, and also not easy to predict?"

2. Ask the participants to write down between three and seven factors of change that will affect land use in the future. These factors may be legal and policy-based, political, environmental, social, economic, or of another type.

3. Facilitators should circulate to ensure that participants understand this activity and respond to any questions or doubts.

\section{Methodology - Part 3: Group work and plenary (45 min.)}

1. Divide groups into homogeneous or "thematic" groups. Groups should consist of participants that work in a similar sphere. Depending on the participants, facilitators should creatively determine how optimally to do this. The following box shows examples of how participants were divided in workshops in Peru. A similar but likely not identical approach should be adopted elsewhere.

\section{Thematic Group Examples}

\section{Example 1}

- Group 1: National government

- Group 2: Civil society and NGOs

- Group 3: Regional/Sub-national Government

- Group 4: Indigenous peoples and organizations 


\section{Example 2}

- Group 1: NGOs and international development/cooperation organizations

- Group 2: Government actors in environmental divisions, regardless of level

- Group 3: Government actors involved in specific economic sectors and divisions, regardless of level (ministries and subnational divisions of agriculture and mining, for example).

- Group 4: Particularly institution with many participants present in the workshop

2. Each group, with the support of a facilitator, should identify five key factors of change. Each individual should share the factors they identified individually, and the facilitator should write them down for discussion.

Through consensus, or if necessary, voting, the group should agree on the five most important and write each one on a card.

3. The facilitators should ask each group to think about the following question for each factor of change identified:

\section{"Are there distinct ways in which this factor might behave in the future? What are the different 'states' in which we might find this factor?"}

The group should discuss, for example, if a price might be high or low, stable or volatile, if migration might increase or decrease, if a policy is more likely to favor one sector or another, etc. The facilitator should pay close attention to this discussion. For example, it may be that in this landscape, the possible states of migration would be to increase or stay the same, but never decrease. These states will be discussed by the facilitators to develop alternative scenarios.

4. Returning to plenary, facilitators should work with participants to consolidate factors. Each group should stick their cards on the wall and explain them. Facilitators should group similar factors (either by writing on a new card to describe two very similar concepts, or by simply sticking one on top of the other if they are virtually identical). At every stage, facilitators should be sure to ask groups if they agree with the suggested consolidation, and ensure that participants feel the outputs from their groups are fairly and completely represented.

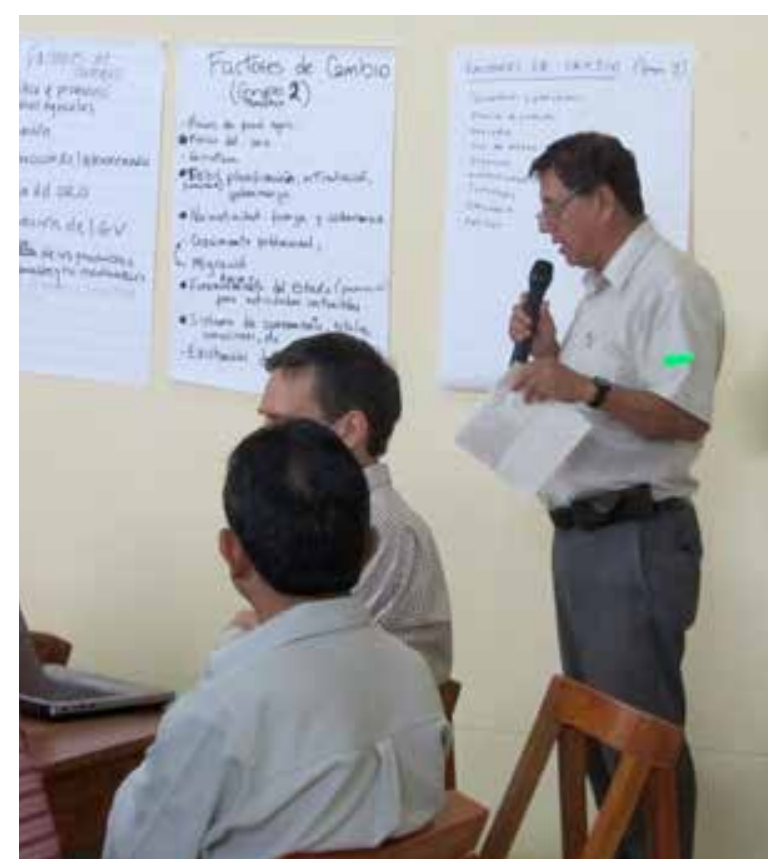

\section{Facilitation notes:}

- There are multiple strategies for forming the thematic/homogeneous groups. Facilitators familiar with the actual land use decision - making processes and multilevel governance institutions in the landscape should use their best intuition to divide the groups up accordingly. A key goal is to avoid power differentials, but also to capture the likely diversity of perspectives that may exist across groups that do not always communicate.

- The outputs of this component of the workshop are key, as they will ultimately shape the scenarios. Facilitators should ensure that participants understand the goals of this component well. In particular, factors of change that really are likely to affect land use should be pulled out through strong facilitation. In addition, factors that are indeed variable should be prioritized by facilitators, with input from participants. 


\section{Selecting the most important and uncertain factors of change}

Approximate time: 30 minutes, plenary and individual

\section{Objective}

The goal of this activity is to select the five most "important" and "uncertain" factors from the list consolidated in the previous stage. To accomplish this in a participatory fashion, each participant will vote for the five factors that they consider to be the most "important," and the five that they consider most "uncertain." Based on the vote, the factors that are widely considered to be most uncertain and also important will be selected to form the basis of the future scenarios.

\section{Methodology}

In plenary, the facilitators should explain the concepts of "importance" and "uncertainty" clearly. The "importance" of a factor is how large of an impact it will have on land use change in the landscape. The "uncertainty" of a factor is how sure we are about which of the various possible states the factor will take on - that is, how unpredictable will the behavior be in the future? In constructing the most interesting future scenarios, it is best to have factors that are both important and also uncertain. It is especially critical that participants understand that uncertain factors are desirable in the context of this activity, and that the goal is precisely to select factors of change with a high degree of uncertainty associated with them.
There are five steps in this activity:

1. Each participant receives five small stickers of one color, and five of a different color.

2. The facilitators explain the concepts of "importance" and "uncertainty."

3. Participants are given five minutes to use their stickers to vote for the factors that they consider most important.

4. Participants are given five minutes to use their stickers to vote for the factors that they consider most uncertain.

5. The facilitators count the votes for uncertainty and importance quickly - a spreadsheet may be used to do this rapidly. Since both importance and also uncertainty are desirable components of the factors of change that are ultimately selected, the five factors that have high vote counts in both categories should be selected.

6. In plenary, the facilitators will present (in a PowerPoint slide) the factors that have been selected by vote, and invite any outstanding commentary and feedback from the group. If there are strong objections to the selection, the facilitators may make adjustments by way of dialogue, consensus, or other appropriate group decision - making strategies.

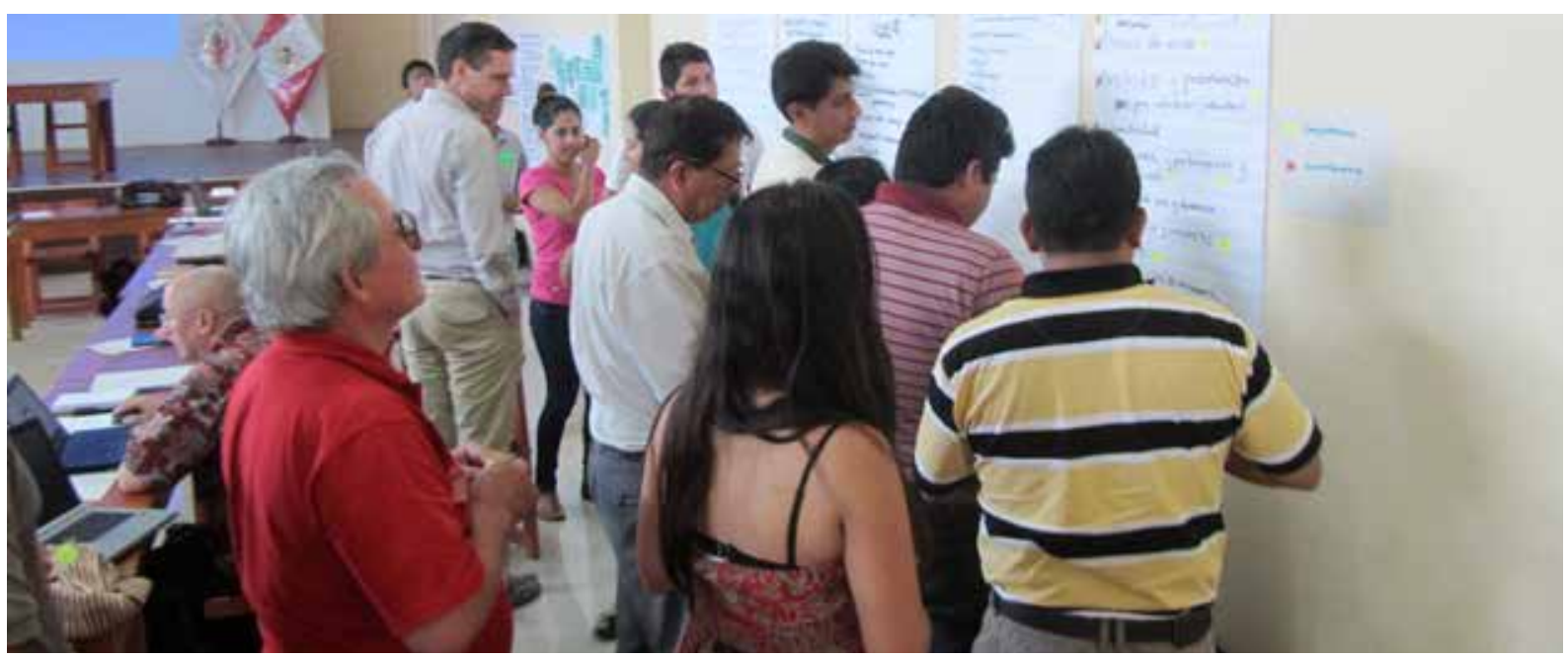




\section{Facilitation notes:}

- Have the participants vote for importance and then for uncertainty in two separate rounds. This avoids confusion between the activities.

- Be very clear in explaining both uncertainty and importance, and ask questions at the end to ensure that all participants understand clearly what these concepts mean. In particular, explain clearly that the factors that are deemed to be both uncertain and important by the group will be selected and used as the basis for the rest of the future scenario building activities.

- Be flexible and adjust the number of stickers (votes) that each participant is given. Although five votes for importance and five votes for uncertainty are suggested here, this should be adjusted based on the number of consolidated factors generated in the previous activity. Five is an appropriate number for between 10 and 15 factors. If there are more factors in the list, then more votes per participant may be required to ensure that relevant and uncertain factors are not excluded. If there are fewer, then fewer votes may be given to each participant to ensure that it is possible to distinguish the most important and uncertain factors.

- If it is not possible to identify five clear factors of change that are deemed both important and uncertain (for example, if only 2 or 3 factors emerge with reasonably high vote counts in both categories), then a second round of voting may be conducted. This second round should exclude any clear winners from the first round.
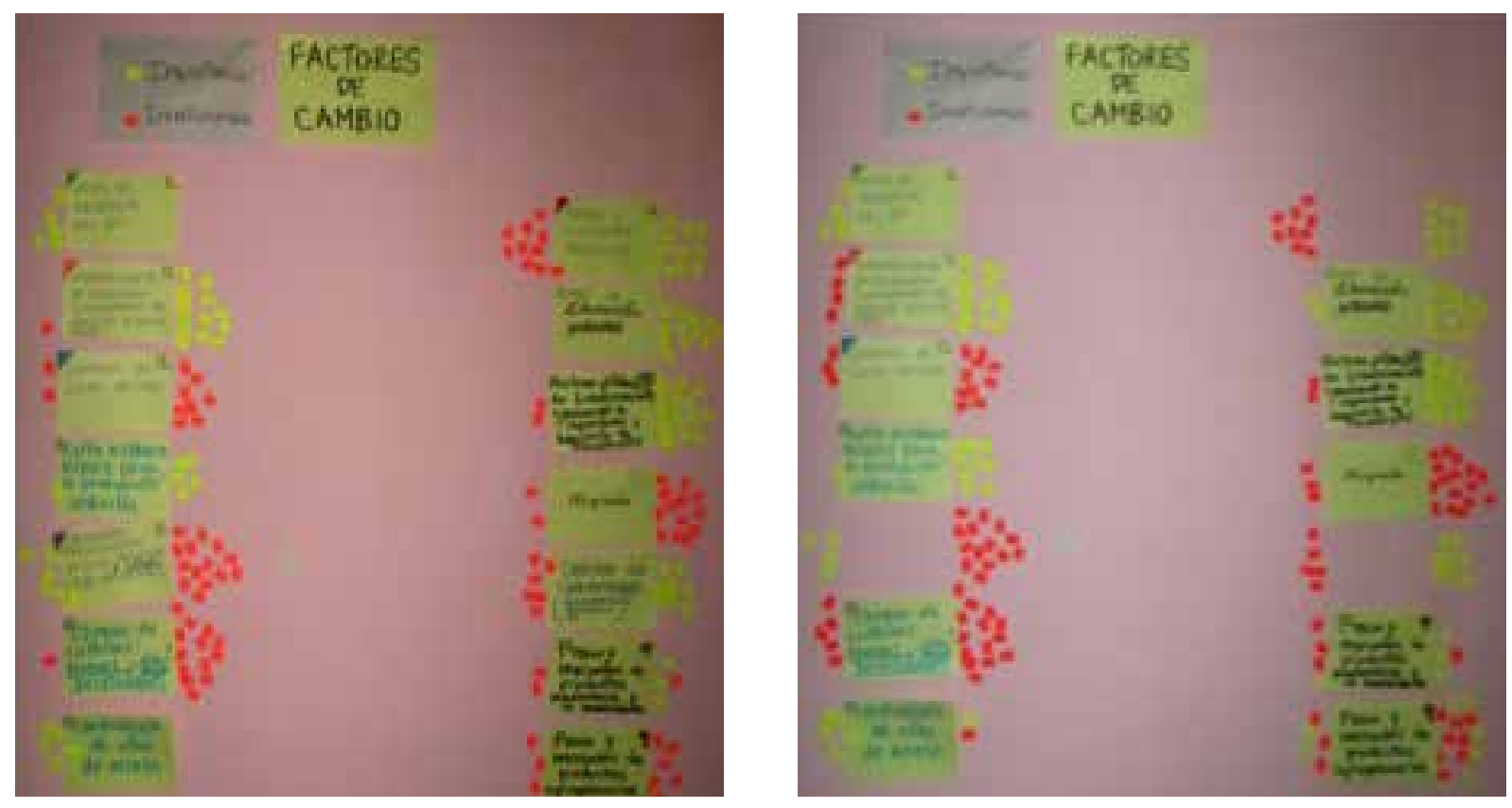

Example of two rounds of voting that were necessary: (CIFOR-VITRI workshop in Moyobamba, Peru, May 6-7, 2014) 


\title{
Constructing future scenarios of land use
}

\author{
Approximate time: 3.5 hours, plenary and group
}

\section{Objective}

This activity generates the main outputs of the first day, and the preceding activities were designed to lead up to this one. Facilitators present distinct scenarios derived from the factors of change identified previously, and the workshop splits into breakout groups, with each group working on one of the proposed scenarios. With the help of a facilitator, each group will develop a scenario narrative. This narrative describes how the world will get to the state described by the factors of change in 30 years. Key plausible events in each decade leading to the scenario described will be elaborated, with associated land use changes from the events described. Finally, participants will draw on a physical map the likely land use changes over time, culminating in a view of land use in the landscape 30 years from the present.

\section{Methodology for defining the distinct scenarios - internal meeting of facilitators (45 min.)}

During lunch break, the facilitators will have an internal meeting amongst themselves. The goal is to use the factors of change and the discussions of alternative states to describe four distinct scenarios.
To do this, the facilitators must think creatively about how the factors of change identified previously might look under distinct scenarios. If divergent carbon content in the landscape is of interest, then facilitators should arrange the states of the factors of change to produce this variation. In addition, facilitators should consider divergence in governance arrangements moving forward, so that distinct governance narratives emerge through this process. The goal is to generate scenarios with some plausibility, with divergence in terms of land use, and interesting and useful governance components for the remaining steps of the workshops. As this is a creative exercise by the facilitators that will necessarily differ depending on the landscape, the context, the specific objectives of the workshop from the facilitators' perspective, and the factors of change that have been identified, some examples are provided below from workshops conducted in Peru. In our workshops, we aimed to present divergent scenarios, such as the most and least desirable, the most conservation-oriented versus development-oriented, and the most likely if nothing were to change. These examples are included to provide an idea of how scenarios can be constructed from the factors of change.
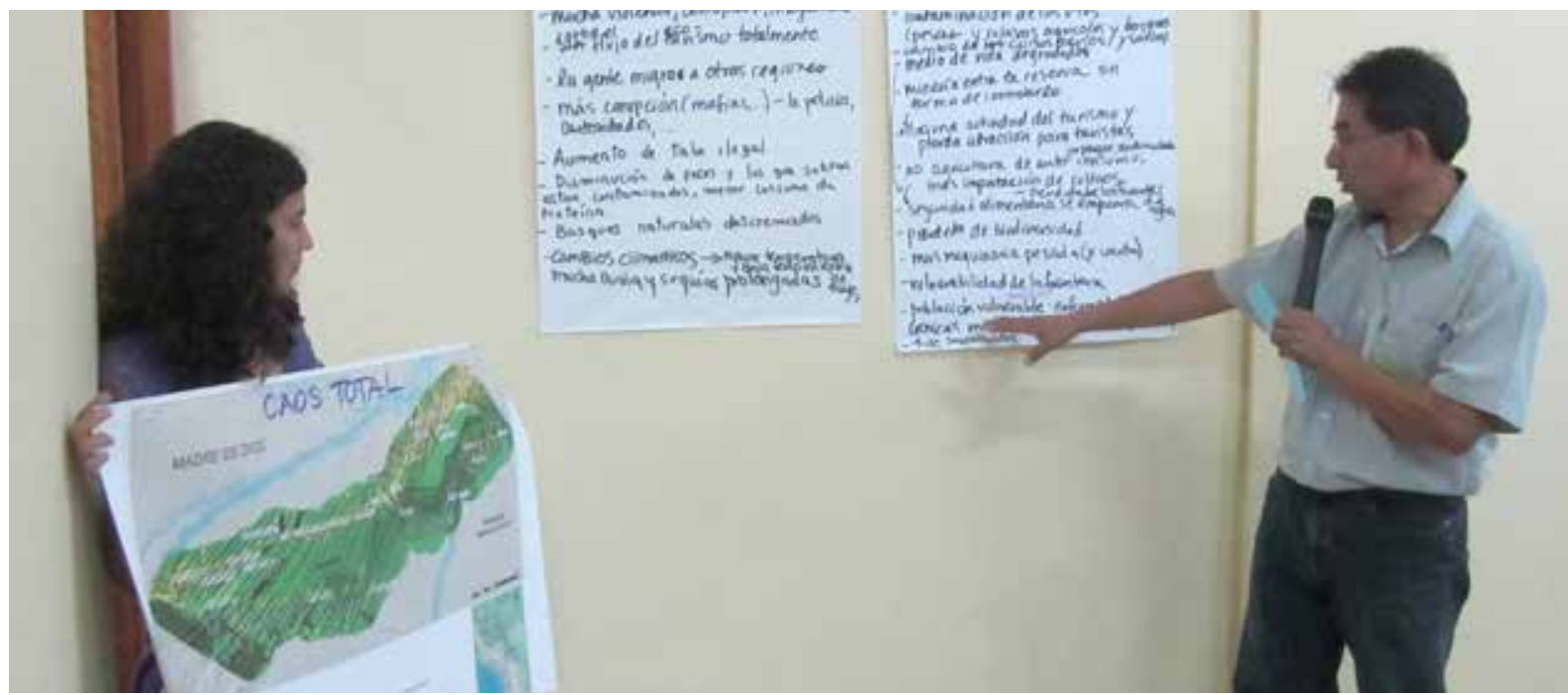
Example 1 of scenario definition (CIFOR workshop in Puerto Maldonado, Peru, May 2-3, 2014)

\begin{tabular}{|c|c|c|c|c|}
\hline Factor of Change & Scenario 1 & Scenario 2 & Scenario 3 & Scenario 4 \\
\hline Price of Gold & $\begin{array}{l}\text { Increases } \\
\text { (very high) }\end{array}$ & Decreases & Decreases & $\begin{array}{l}\text { Remains as is, with } \\
\text { some variability but still } \\
\text { quite high }\end{array}$ \\
\hline $\begin{array}{l}\text { Regional government } \\
\text { policies for land } \\
\text { use (support for } \\
\text { conservation, cash } \\
\text { crops, or otherwise) }\end{array}$ & None & $\begin{array}{l}\text { Support for } \\
\text { monocrops and } \\
\text { agriculture oriented } \\
\text { to the export market }\end{array}$ & $\begin{array}{l}\text { Support for sustainable } \\
\text { agriculture, agroforestry, } \\
\text { sustainable forest } \\
\text { management, and } \\
\text { REDD+ }\end{array}$ & $\begin{array}{l}\text { Support for sustainable, } \\
\text { ordered and regulated } \\
\text { gold mining }\end{array}$ \\
\hline $\begin{array}{l}\text { Price of agricultural } \\
\text { crops }\end{array}$ & $\begin{array}{l}\text { Low and } \\
\text { volatile }\end{array}$ & Increasing, high & Remains as is & Remains as is \\
\hline Use rights & $\begin{array}{l}\text { No change } \\
\text { (status quo } \\
\text { maintained) }\end{array}$ & $\begin{array}{l}\text { Well defined, with } \\
\text { policies that support } \\
\text { parecelization and } \\
\text { privatization }\end{array}$ & $\begin{array}{l}\text { Well defined, with } \\
\text { support for communal } \\
\text { property rights; less } \\
\text { privatization. }\end{array}$ & $\begin{array}{l}\text { Well defined with } \\
\text { support for communal } \\
\text { property rights and } \\
\text { formalization of mining } \\
\text { rights }\end{array}$ \\
\hline Immigration & $\begin{array}{l}\text { Increases } \\
\text { considerably }\end{array}$ & Increases & Remains as is (fairly high) & Decreases \\
\hline Governance & Poor & Poor & Good & Good \\
\hline
\end{tabular}

Example 2 of scenario definition (CIFOR workshop in Moyobamba, Peru, May 6-7, 2014)

\begin{tabular}{|c|c|c|c|c|}
\hline Factor of Change & Scenario 1 & Scenario 2 & Scenario 3 & Scenario 4 \\
\hline $\begin{array}{l}\text { Regional Policies } \\
\text { and Priorities }\end{array}$ & $\begin{array}{l}\text { The regional } \\
\text { government } \\
\text { deprioritizes } \\
\text { conservation, } \\
\text { prioritizing support } \\
\text { for export crops (coffee, } \\
\text { papaya, rice, and/or } \\
\text { oil palm) }\end{array}$ & $\begin{array}{l}\text { The regional } \\
\text { government } \\
\text { prioritizes and } \\
\text { supports conservation } \\
\text { and sustainable } \\
\text { agroforestry }\end{array}$ & $\begin{array}{l}\text { The regional government takes } \\
\text { actions that lead to migration } \\
\text { and parcelization (with private } \\
\text { titles) of the buffer zone of the } \\
\text { Alto Mayo protected forest, } \\
\text { and the native territory of the } \\
\text { Awajun indigenous people }\end{array}$ & $\begin{array}{l}\text { The regional } \\
\text { government } \\
\text { prioritizes both } \\
\text { conservation } \\
\text { and intensive } \\
\text { agriculture for } \\
\text { export }\end{array}$ \\
\hline $\begin{array}{l}\text { Prices and markets } \\
\text { for agriculture and } \\
\text { livestock }\end{array}$ & $\begin{array}{l}\text { High price for export } \\
\text { crops }\end{array}$ & $\begin{array}{l}\text { Low prices for } \\
\text { traditional crops, } \\
\text { with higher prices } \\
\text { for certified and } \\
\text { sustainable alternative } \\
\text { crops }\end{array}$ & High prices & $\begin{array}{l}\text { Very high } \\
\text { prices }\end{array}$ \\
\hline $\begin{array}{l}\text { Implementation } \\
\text { of innovative } \\
\text { conservation } \\
\text { incentives and } \\
\text { payments for } \\
\text { environmental } \\
\text { services }\end{array}$ & $\begin{array}{l}\text { No incentives for } \\
\text { conservation, and no } \\
\text { REDD+ }\end{array}$ & $\begin{array}{l}\text { Considerable } \\
\text { advances in REDD+ } \\
\text { and other PES } \\
\text { mechanisms }\end{array}$ & None & $\begin{array}{l}\text { Moderate } \\
\text { finance for } \\
\text { REDD+ and } \\
\text { support for } \\
\text { other PES } \\
\text { mechanisms }\end{array}$ \\
\hline $\begin{array}{l}\text { Decentralization of } \\
\text { budget }\end{array}$ & Decentralized budget & Decentralized budget & Centralized Budget & $\begin{array}{l}\text { Highly } \\
\text { centralized } \\
\text { budget }\end{array}$ \\
\hline $\begin{array}{l}\text { Quality of } \\
\text { governance }\end{array}$ & High & Very high & Very low & Low \\
\hline
\end{tabular}


Methodology for characterizing the four scenarios in terms of land use and estimating the areas of land use change at the landscape scale: plenary and breakout groups (3 hours)

\section{Presenting scenarios to participants} (10 minutes)

In plenary, the facilitators will present the different scenarios to the participants and invite feedback. In particular, participants may point out that some of combinations of factors are incoherent (in example 1 above, participants noted that reduced migration was incompatible with a high price of gold, and one of the scenarios was adjusted accordingly).

\section{Explain the activity to participants} (10 min)

In plenary, the facilitators should explain carefully the activities that will be carried out in breakout groups. Describe the construction of scenario narratives, and the eventual map work that will be done. Make sure that participants understand the goals of the following activities clearly. More detail on these activities is given below.

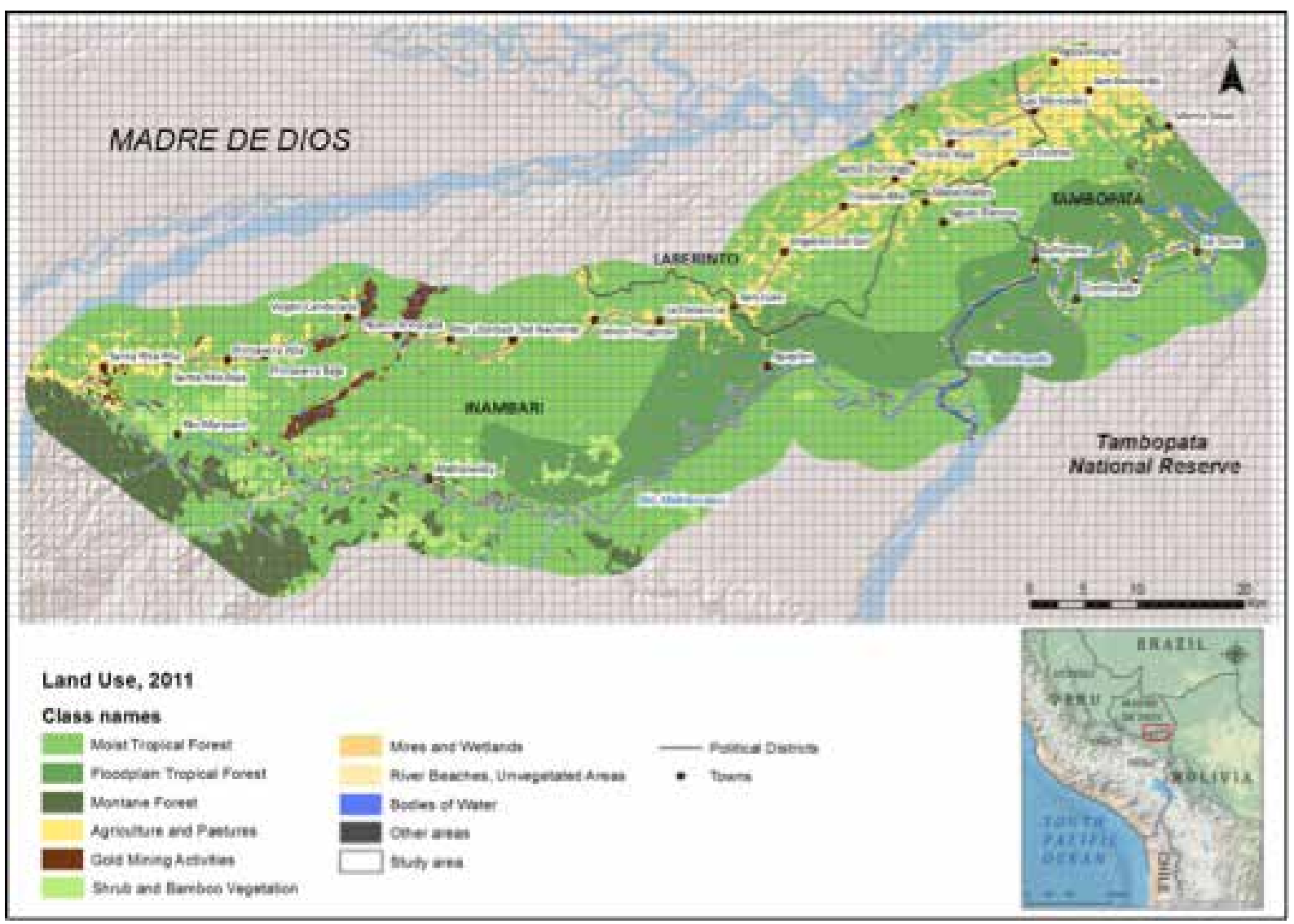

Example Map: Current land use in the buffer zone of the Tambopata Reserve (CIFOR workshop in Puerto Maldonado, Peru, May 2-3, 2014)

Source: Viikki Tropical Resources Institute - VITRI, University of Helsinki 


\section{Analysis, scenario description, and narrative ( 1.5 hours)}

The facilitator will lead a group discussion to think deeply about how the world might arrive at the state defined by the factors of change for the scenario. In particular, the group should think about what key events will have to occur to bring about the world described in the scenario. What policies will be implemented? When will they be implemented? What changes will have to occur and when? Why will these changes occur? What consequences will they have? What are the key moments in the next 30 years?

Facilitators should ask respondents to describe the narrative in 10 - year stages. What is likely to happen in each decade? What needs to happen to bring the landscape to the condition described by the factors of change? What does this mean for land use?

\section{Facilitation notes:}

- It can be useful to decompose the narrative into political, economic, environmental, cultural, and social aspects. At the same time, these other aspects of the future scenario narrative should link to land use, especially given the time constraints. Facilitation should aim to bring the discussion back to land use change.

- If the participants in a group find some aspect of the scenario to be incoherent or problematic, facilitators should be flexible and invite changes to the factors of change as needed.

- Record the scenario narrative in bullet points on a sheet of poster paper to share later in plenary

\section{Implications in terms of land use}

Once scenario narratives have been developed, facilitators should have the participants draw land use changes on the grid-box map using colored markers (if the carbon tool is used, the changes from one land use to another will be quantified using the grid to be entered into the carbon calculator). Any color can represent any land use change type all colors used should be indicated in a legend.

\section{Facilitation notes:}

- Since different changes may occur at different times, facilitators should be clear in marking with different shading when changes occur.

- It's important to mark the legend clearly so that the map can be read.

- Drawing in pencil or pen before coloring is useful - it is better to arrive at a consensus first rather than coloring the map in too eagerly.

\section{Select a name for the scenario}

Facilitators should ask the group members to come up with a name that describes the scenario.

\section{Explanation of scenarios in plenary (50 min.)}

All workshop participants should move around the room to see the outputs from the other groups. In sequence, each group will select a representative to explain the scenario narrative and show the changes drawn on the map. Participants from other groups can ask questions or provide feedback. 
Example maps of land use change under distinct scenarios (CIFOR-VITRI workshop, Puerto Maldonado, Peru, May 2-3, 2014)

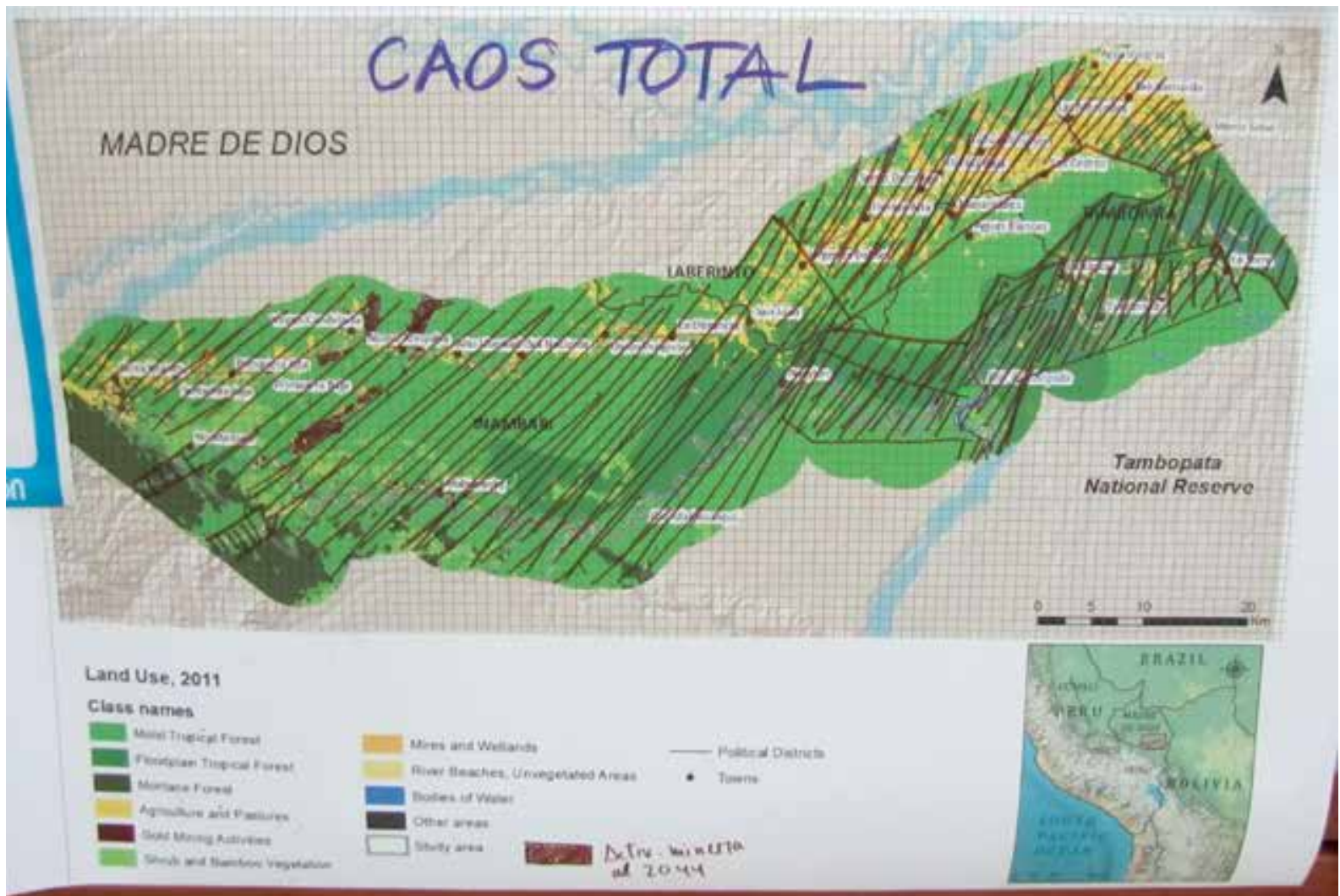

Scenario 1: "Total Chaos”

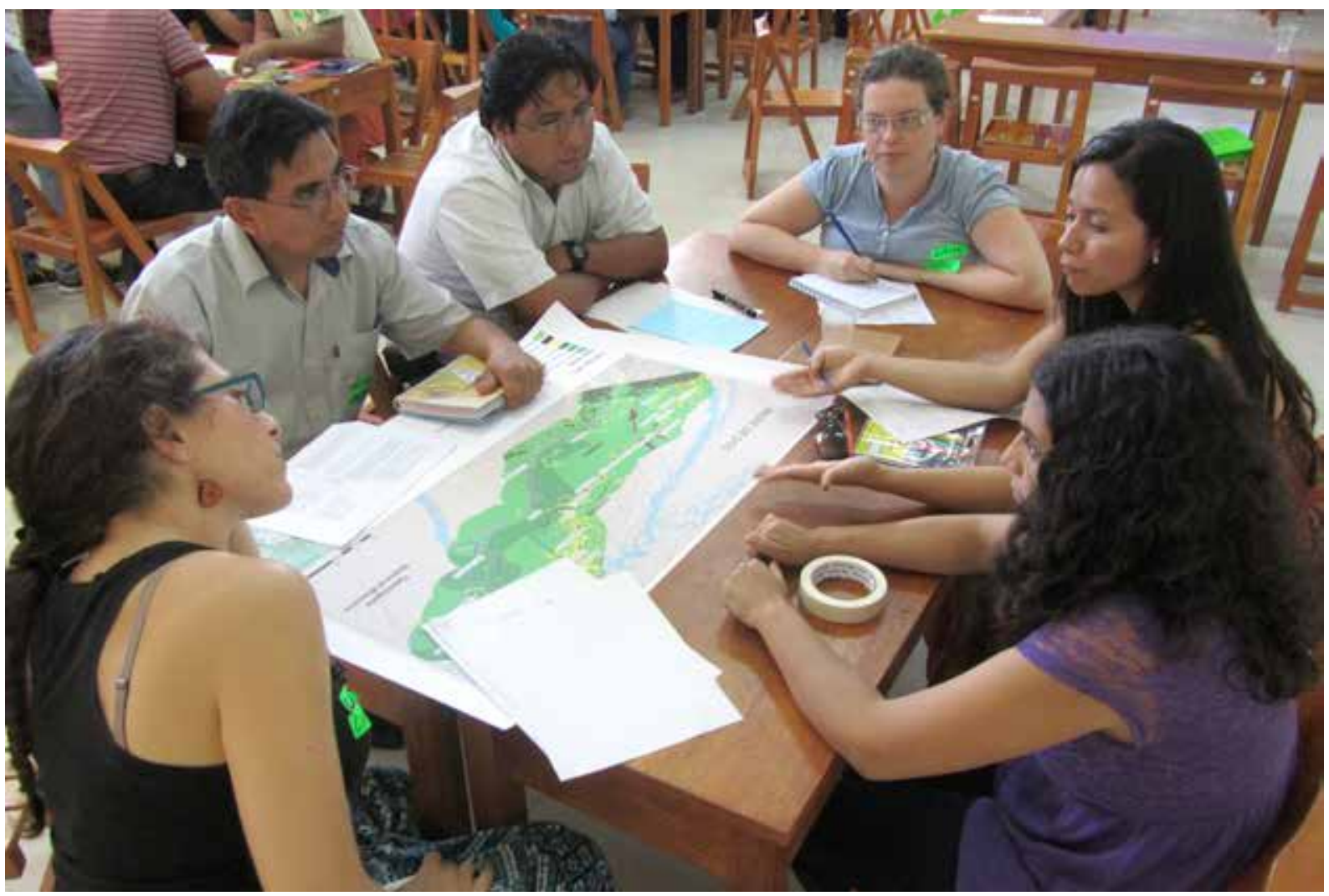




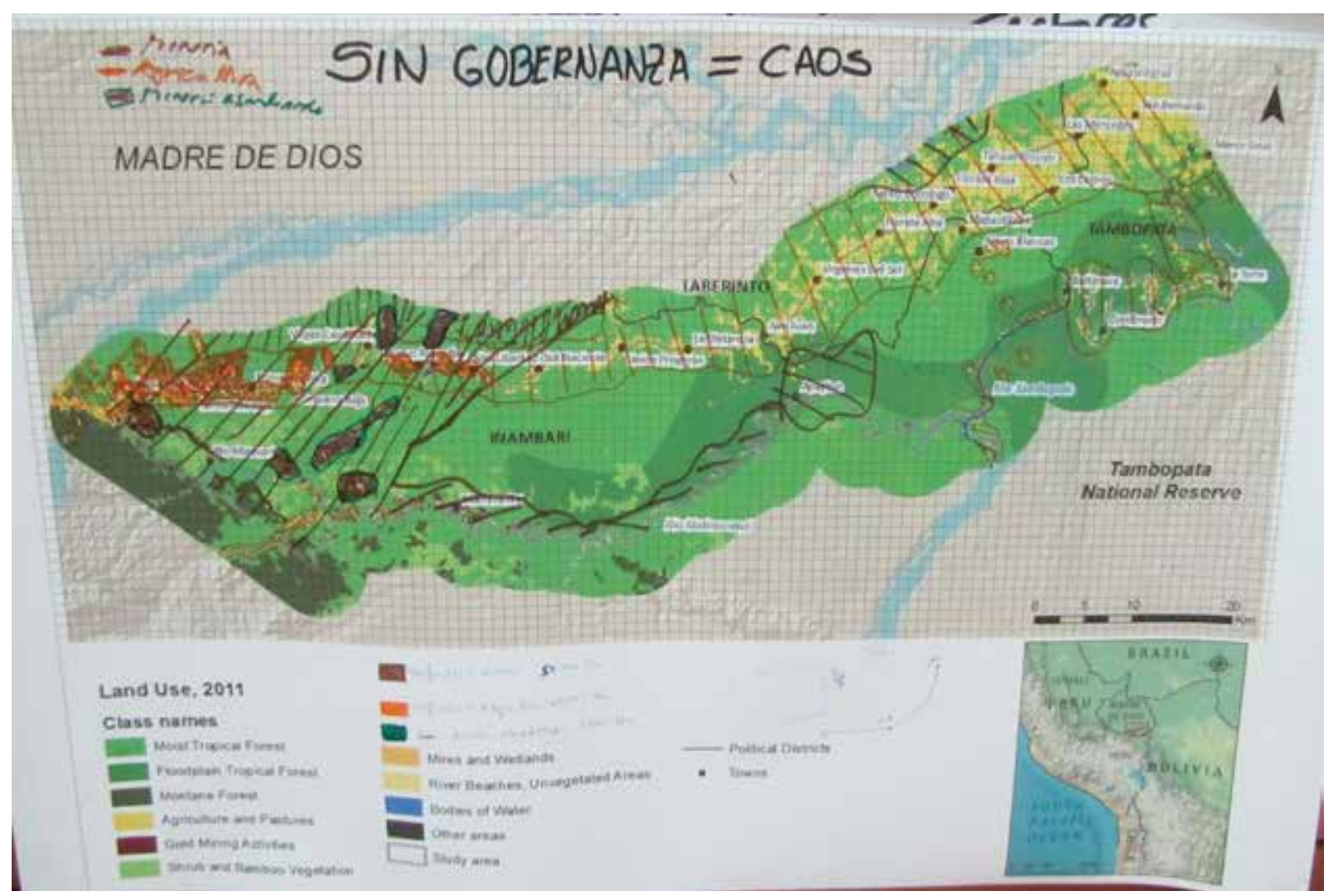

Scenario 2: "No governance $=$ chaos"

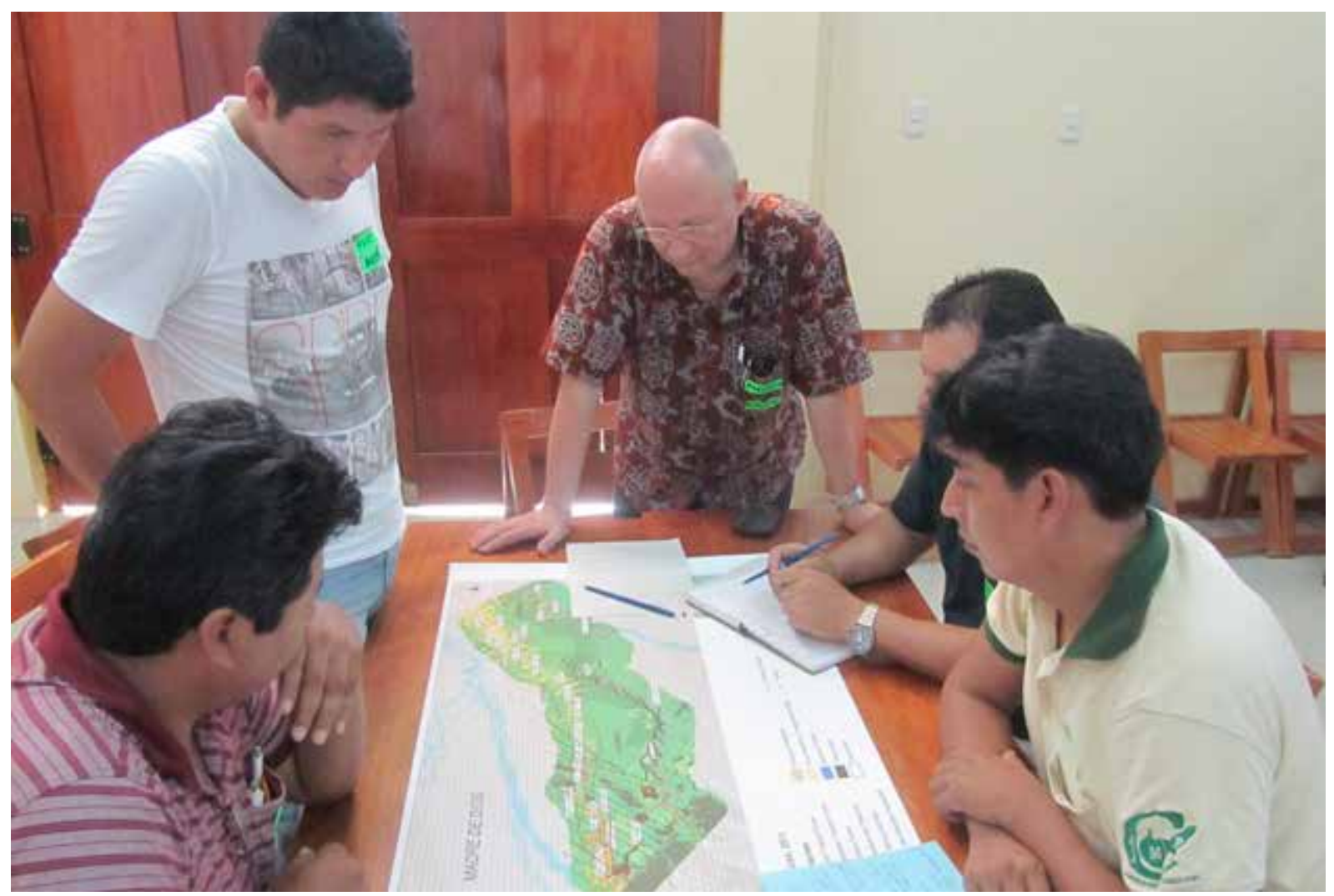




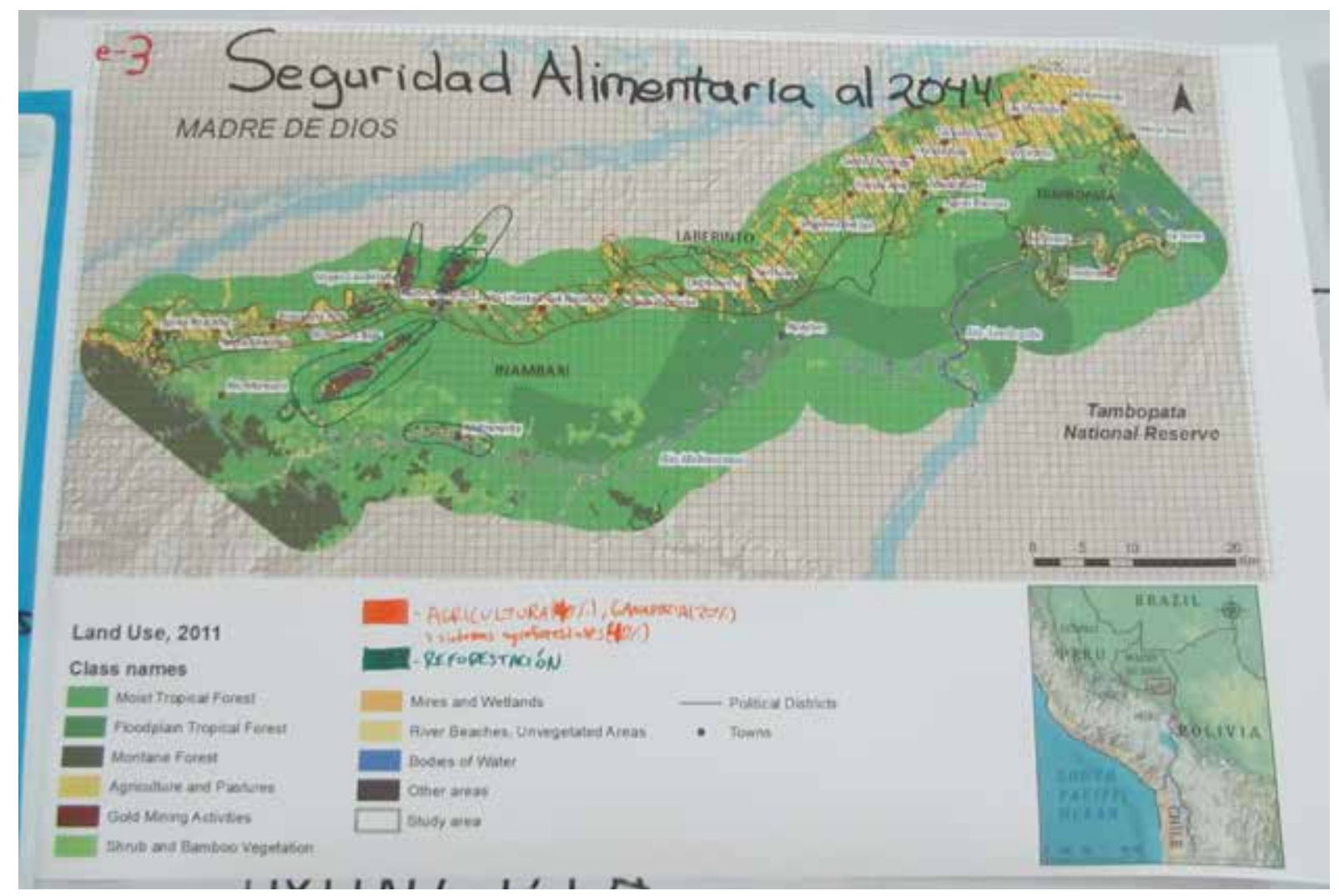

Scenario 3: "Food Security in 2044"

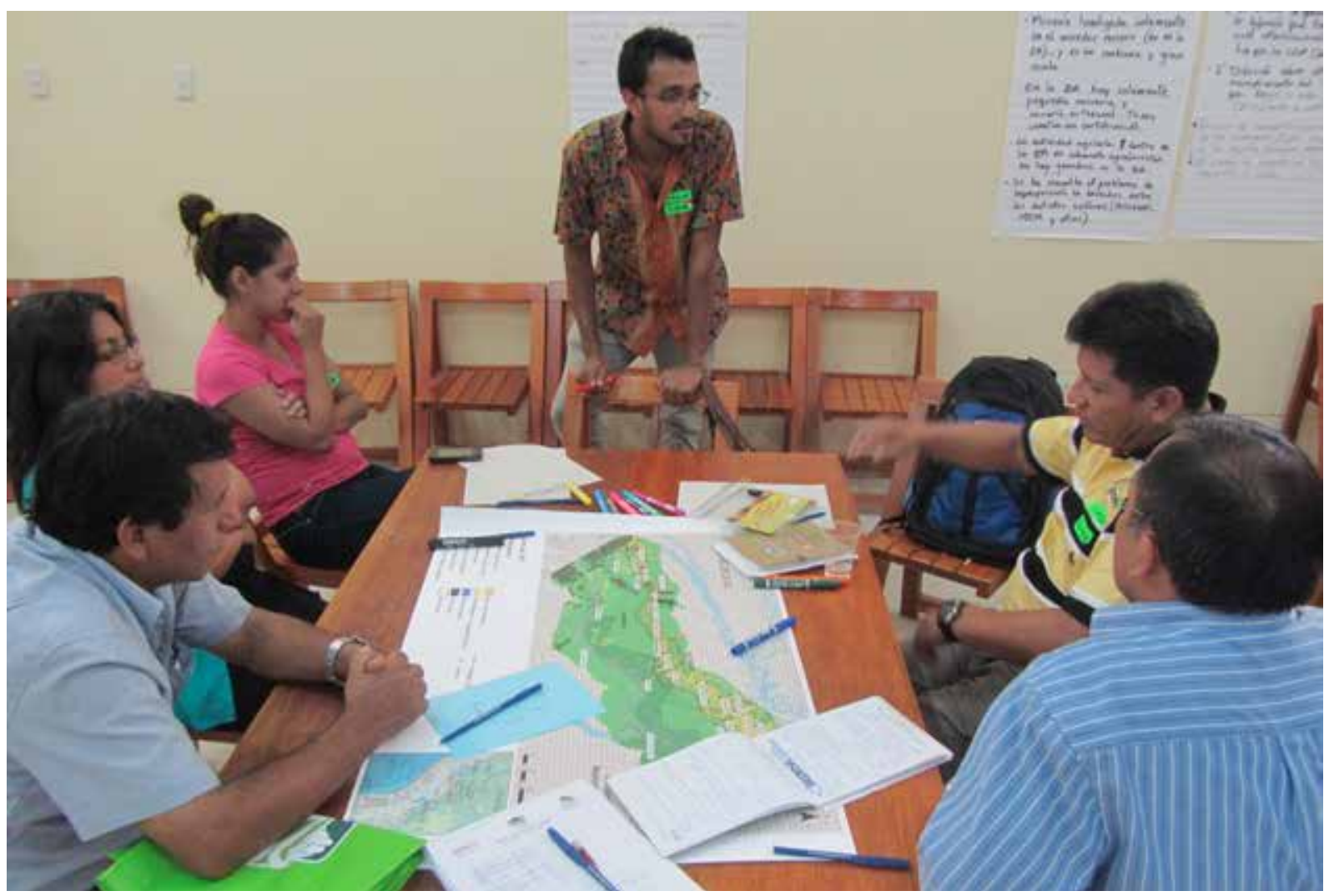




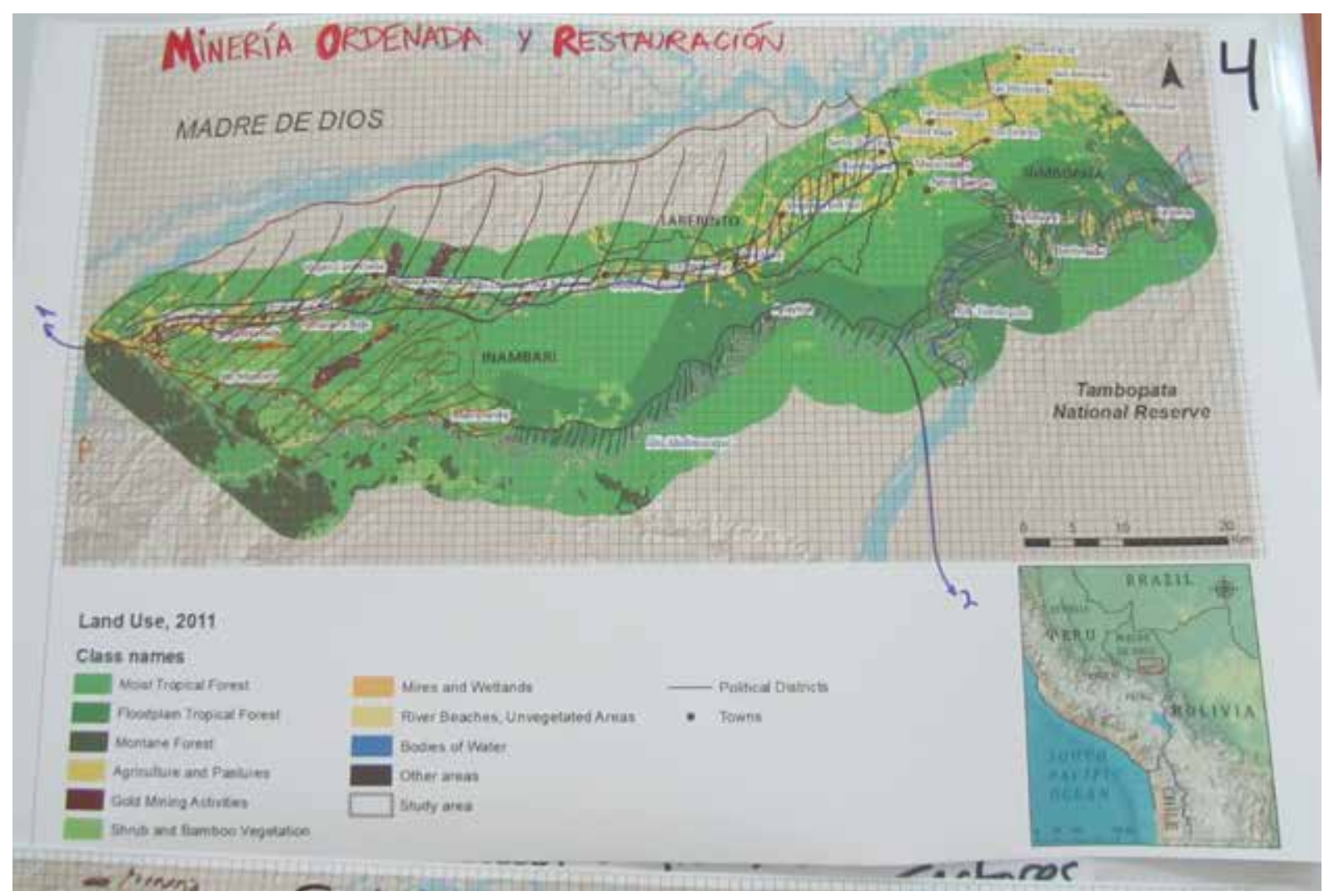

\section{Scenario 4: "Ordered Mining and Restoration"}

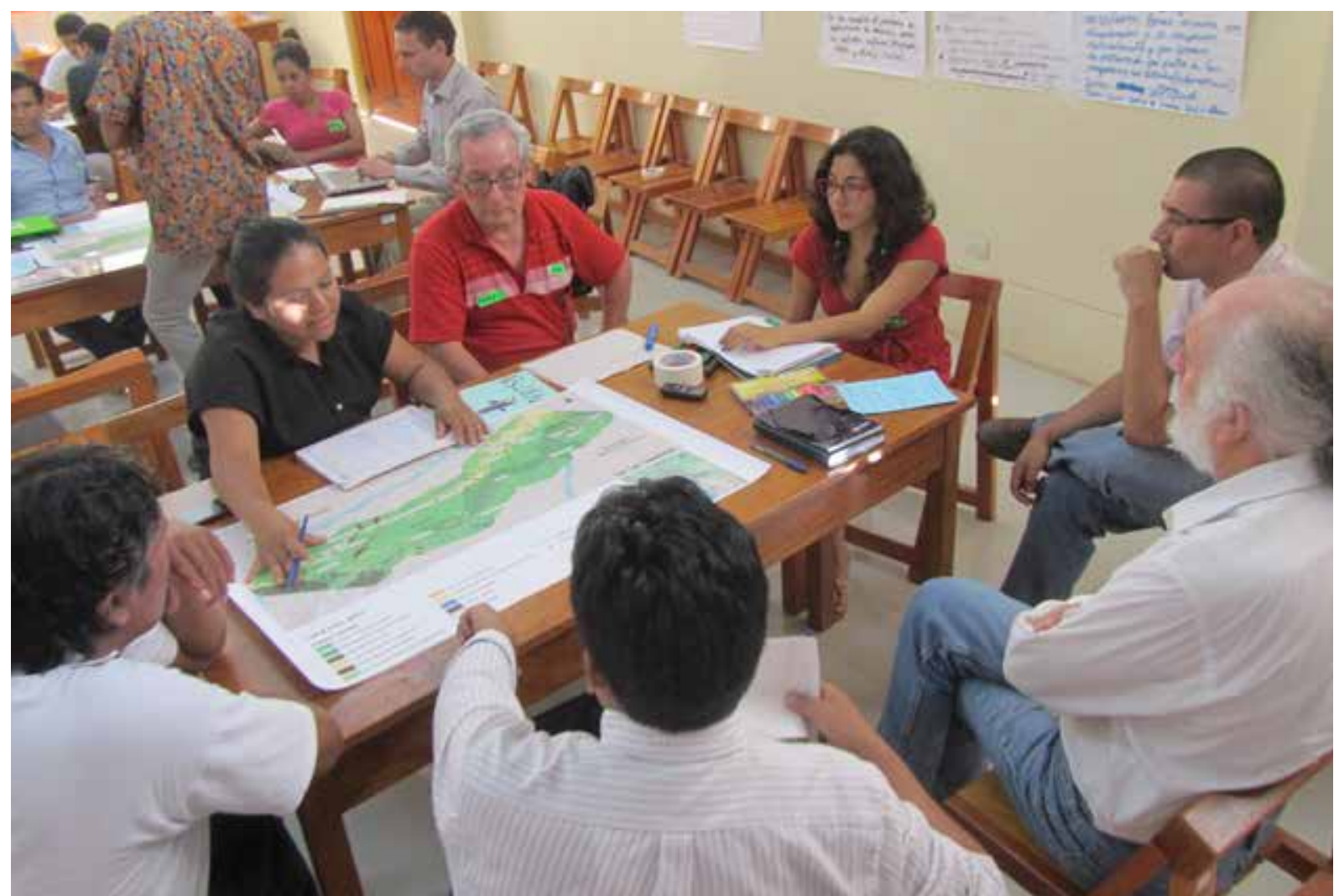




\section{End of day survey: linking scenarios and governance}

Approximate time: 30 minutes, individual work

\section{Objective}

The goals of the survey are (1) to assess which scenario(s) the group deems most desirable to guide activities on the following day, and (2) to gain perspective on the participants' perceptions of their role in the governance of land use in the landscape in practice.
The following questions should be distributed to participants to ascertain which scenario they deem most desirable and which they deem most probable:

\section{Survey on future scenarios}

Take a moment to reflect on the scenarios developed today:

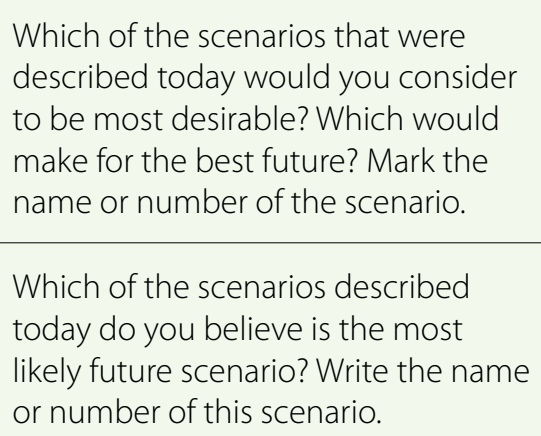

Remember that your response is anonymous 
In addition, the following survey may be administered to better understand the role of participants in land use governance in the real world.

\section{Workshop survey}

\begin{tabular}{|l|l|}
\hline Name (Optional) & \\
\hline Institution & \\
\hline
\end{tabular}

1. Please mark the degree to which you agree or disagree with the following statements about land use decisionmaking. On a scale of $1-5(1=$ strongly disagree, $5=$ strongly agree), how do you feel about the following statements?

\begin{tabular}{|l|l|l|l|l|l|}
\hline & $\begin{array}{c}\text { 1. (strongly } \\
\text { disagree) }\end{array}$ & 2. (disagree) & $\begin{array}{c}\text { 3. (neither } \\
\text { agree nor } \\
\text { disagree) }\end{array}$ & 4. (agree) & $\begin{array}{c}\text { 5. (strongly } \\
\text { agree) }\end{array}$ \\
\hline $\begin{array}{l}\text { a. I have the information } \\
\text { I need to participate } \\
\text { in decision-making } \\
\text { about land use }\end{array}$ & & & & \\
\hline $\begin{array}{l}\text { b. If I need information, I } \\
\text { can get it }\end{array}$ & & & & & \\
\hline $\begin{array}{l}\text { c. My organization or } \\
\text { institution is well } \\
\text { represented in land } \\
\text { use decision making }\end{array}$ & & & & & \\
\hline $\begin{array}{l}\text { d. My organization } \\
\text { or institution has } \\
\text { influence in decision } \\
\text { making about land } \\
\text { use }\end{array}$ & & & & & \\
\hline $\begin{array}{l}\text { e. I should be more } \\
\text { involved than I am } \\
\text { in decision making } \\
\text { about land use }\end{array}$ & & & & \\
\hline
\end{tabular}

4. Would you like to share any other thoughts or feedback with us? 


\section{DAY 2}

\section{CARBON MODELING AND GOVERNANCE MONITORING}

\section{Proposed agenda}

\begin{tabular}{ll}
\hline TIME & ACTIVITY \\
\hline 08:30-9:00 & Participant registration \\
\hline 09:00-09:30 & Recap of day one, and day two agenda \\
\hline 09:30-11:00 & $\begin{array}{l}\text { Modeling carbon emissions } \\
\text { Presentation of the VITRI methodology for modeling carbon emissions from distinct land use } \\
\text { scenarios, and demonstration of the carbon implications of the scenarios developed in day } \\
\text { one. }\end{array}$ \\
\hline 11:00-11:15 & Break \\
\hline 11:15-13:00 & Activities and steps towards desirable future scenarios \\
\hline 13:00-14:00 & Lunch \\
\hline 14:00-15:00 & $\begin{array}{l}\text { Multilevel Governance } \\
\text { Discussion and presentation of key aspects of multilevel governance }\end{array}$ \\
\hline 15:00-16:00 & $\begin{array}{l}\text { Multilevel Governance: Monitoring and Indicators } \\
\text { Discussion of multilevel governance monitoring and elaboration of indicators }\end{array}$ \\
\hline 16:16:16-16:45 & Break and "energizer" \\
\hline
\end{tabular}


Briefly summarize the previous day's activities, and go over the agenda for the day. Present the findings of the previous day's survey on desirable and probable scenarios. If necessary, due to lack of responses the previous day or if there is a change of participants, this survey can be repeated after a short review of the four scenarios.
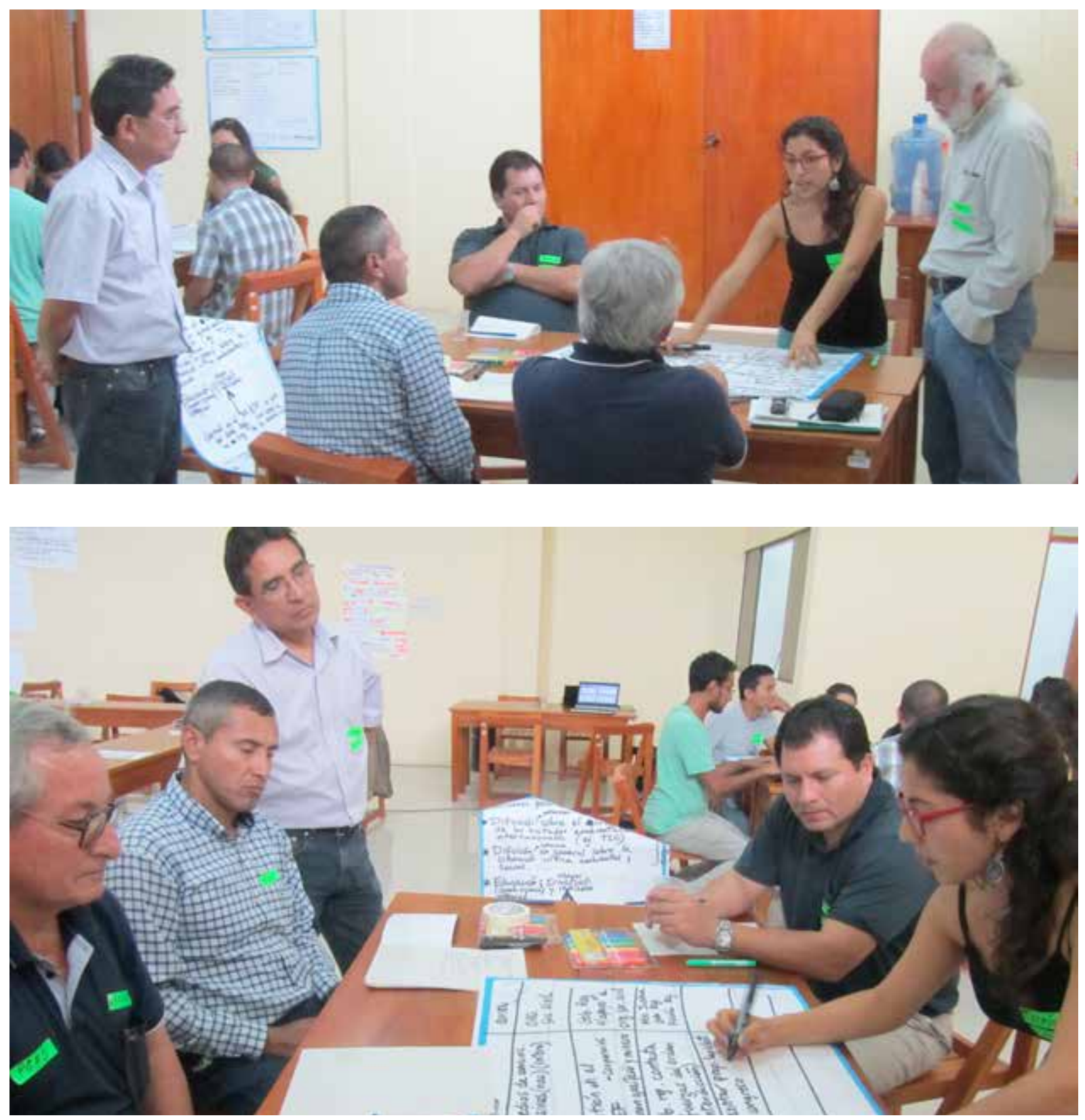


\section{Carbon modeling: implications of future scenarios for carbon}

Approximate time: 1.5 hours, plenary

\section{Objective}

The goal of this activity is to explain the link between land use and carbon emissions and show the carbon implications of the scenarios developed during the previous day using a simple carbon calculator.

\section{Methodology 4}

1. Presentation of the carbon modeling methodology (30 $\mathrm{min}$ )

Explanation of the carbon calculator, and the pieces of information it requires:

a. Carbon density of different land use classes

b. Rate of change in carbon density of land as land use changes

c. Current land use

d. Future land use
The facilitators will explain that the first three pieces of information were gathered through previous research, while the final piece - future land use scenarios - was ascertained the previous day through this workshop.

2. Presentation of preliminary results from previous day (30 $\mathrm{min}$ )

Results from the carbon calculator using the scenarios developed on the first day of the workshop will be presented.

\section{Round of questions (30 min)}

Feedback and questions are taken from participants.

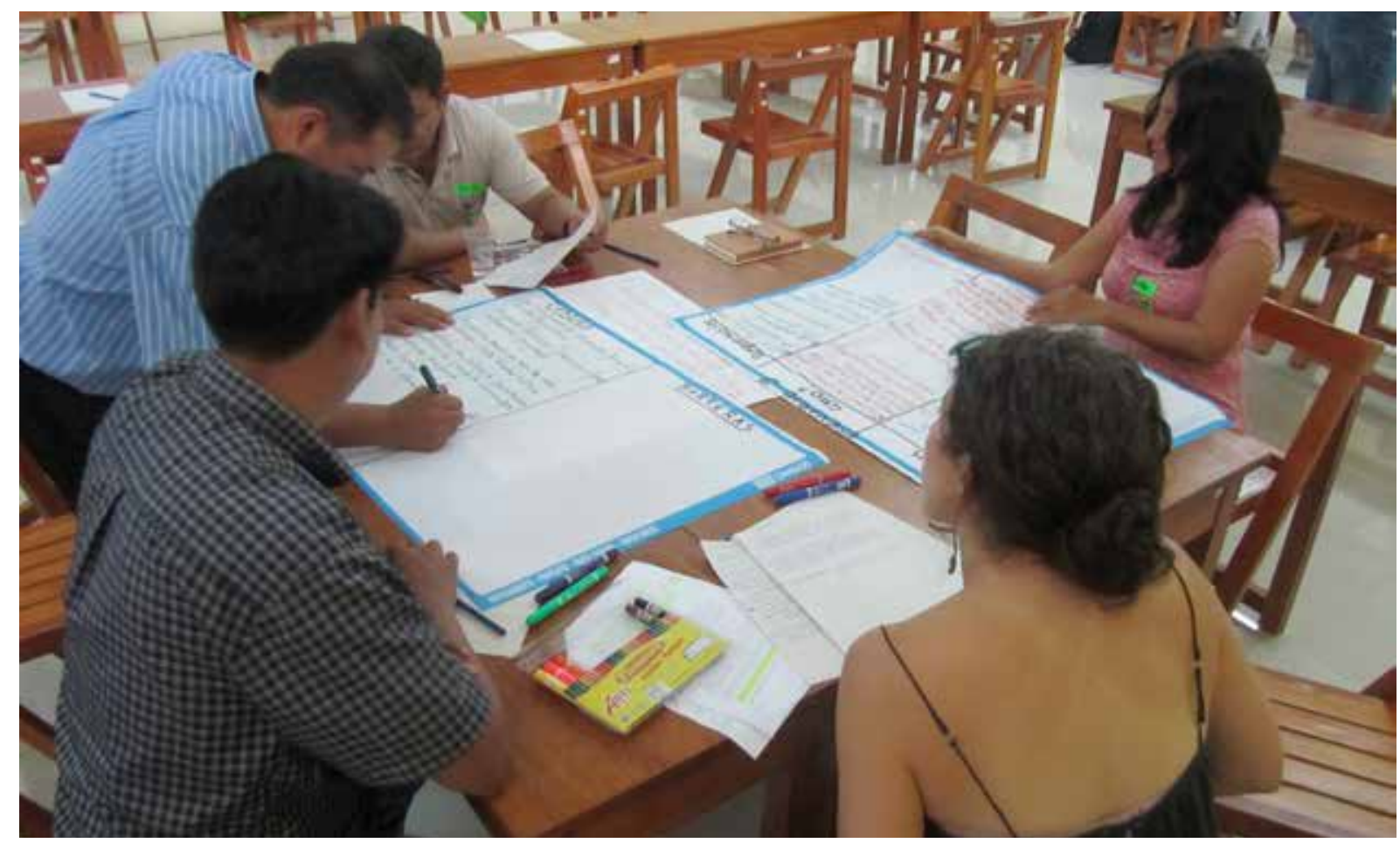

4 This carbon tool and a full explanation will be available on the CIFOR web site in 2015. 


\title{
Identifying strategies to reach a desirable future
}

\author{
Approximate time: $1-1.5$ hours (individual and breakout groups)
}

\section{Objective}

The goal of this activity is to identify key activities and steps to reach a desirable future scenario.

\section{Methodology:}

After a period of individual reflection, participants will be divided into groups randomly or according to the scenario that they deemed most desirable, in order to answer the following questions. To reach the desirable future scenario (described the previous day, but not strictly constrained by its parameters), (1) what needs to be done? what strategies, steps and activities must be undertaken? (2) how will these things be accomplished?, (3) who will be in charge of taking these steps?, (4) what are the barriers to taking these steps? and (5) how can these barriers be overcome?

\section{Individual work (15 min)}

Facilitators will explain that while the previous day was about describing future scenarios, today is about governance and what it might take to improve processes aimed at moving towards desirable scenarios. Ask participants to reflect on what would need to be done to reach a desirable future. Who would have to do what? How would these things be done? What key strategies would need to be adopted? Participants should write down some ideas - activities, steps, and strategies - on a piece of paper.

\section{Group work (1 hour)}

Participants should divide into groups based on which scenario they elected as most desirable from the previous day, or randomly if all (or many) agreed on the same one.

\section{Facilitation notes:}

- Each group should have approximately 5 people and no more than 8 . If most participants selected just one scenario, then multiple groups can work with the same scenario. In addition, explain that the specific constraints of the scenario are not strict for today's activities. Rather, they form a basis for what the "desirable future" is, but other desirable aspects of a preferred future can also be incorporated in today's group work.

Each group should have a facilitator who asks each group member to share their reflections. The facilitator should note the strategies, activities, and steps that participants share in a table such as the one below (either on a poster paper sheet, or on colored paper to stick to poster paper later):

\begin{tabular}{lll}
\hline $\begin{array}{l}\text { What needs to be done } \\
\text { (strategy or activity) }\end{array}$ & $\begin{array}{l}\text { How will this strategy be realized/how will } \\
\text { this activity be done? }\end{array}$ & $\begin{array}{l}\text { Who will have to do these } \\
\text { things? }\end{array}$ \\
\hline Strategy 1 & & \\
\hline Strategy 2 & \\
\hline Strategy 3 & \\
\hline Strategy 4 & \\
\hline Strategy 5 & \\
\hline
\end{tabular}


Facilitators should then ask participants to think about key barriers to realizing these strategies. Up to five barriers should be noted. Participants may identify barriers in a general sense, or may identify barriers for the specific strategies identified. Either approach is acceptable, depending on the group's dynamic and preference. For each barrier, participants should note some ways that it might be overcome.

\section{Presentation of Group Work (45 min)}

Circulating around the room, each group should present its outputs to the other participants. After the last presentation, facilitators should ask participants to identify and discuss similarities and differences between the groups' outputs. This is a discussion topic that can promote broader thinking in the next activity.

\begin{tabular}{ll}
\hline Barriers & How to overcome the barrier? \\
\hline \\
\hline
\end{tabular}

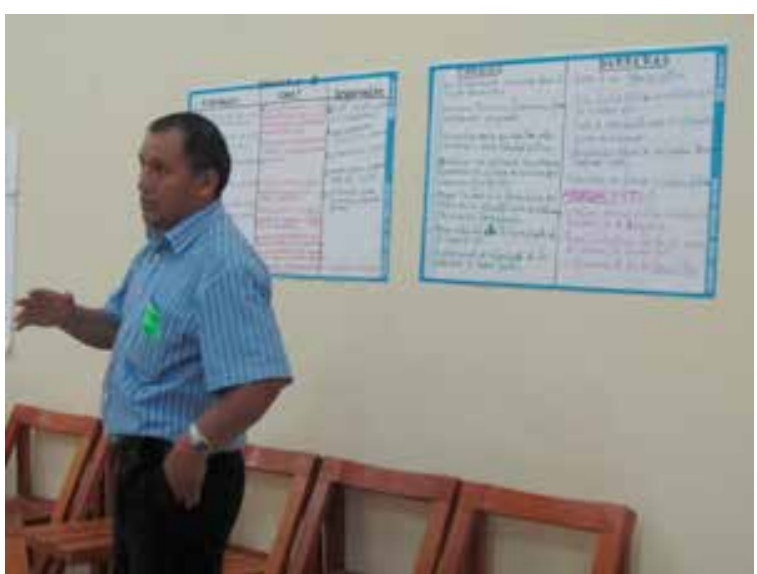

\begin{tabular}{|c|c|c|}
\hline QUE HACER & como & QUIEN \\
\hline 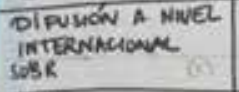 & $\begin{array}{l}\text { Medios de omume. } \\
\text { mésives (nac) (inten) }\end{array}$ & $\begin{array}{l}\text { ORG. } \\
\text { Soc civil }\end{array}$ \\
\hline 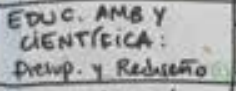 & $\begin{array}{l}\text { - Gestión on el } \\
\text { MEF -coopersion } \\
\text { - canen gosifero y miners }\end{array}$ & $\begin{array}{l}\text { Gob.h } \\
\text { Gapey } \\
\text { ora. Gox }\end{array}$ \\
\hline 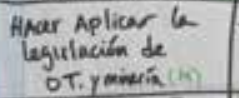 & $\begin{array}{l}\text { - Gob. ry. corrtacta } \\
\text { a fuerzas dal orden } \\
\text { (interdicuent) }\end{array}$ & 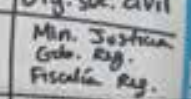 \\
\hline 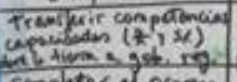 & 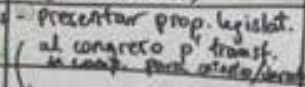 & 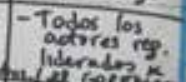 \\
\hline Oepleter d proasis & $1-6$ & \\
\hline 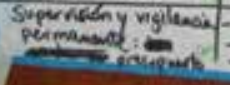 & 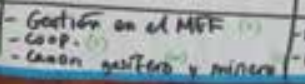 & 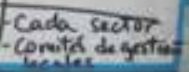 \\
\hline
\end{tabular}




\section{Governance: Conceptual discussion}

Approximate time: 45 minutes, individual, plenary, and group work

\section{Objective}

The purpose of this activity is to make sure that everyone is on the same page with respect to the definition of the term "governance." Although the term has likely been mentioned many times at this point in the workshop, different people may have different ideas about what it means. The facilitation team will provide a definition after hearing from the participants about their ideas on what the term is, ensuring that the participants have a shared understanding.

\section{Methodology}

One facilitator will lead this activity. After having a participatory brainstorm on the definition of "governance," the facilitator will present an expert definition.

\section{Individual reflection on governance (10 min)}

The facilitator will ask each participant to write down what they believe the term "governance" means. They may prompt, "by now, we have all heard the term 'governance' before. But what does it mean? How do you understand the concept? Write down a brief definition of how you understand governance."

\section{Brainstorm in plenary (10 min)}

Ask participants to share their reflections.

\section{Facilitation notes:}

- A member of the facilitation team should type up participants' responses in real time

- Emphasize that only definitions that differ from what has already been shared should be mentioned

- As responses are noted in the powerpoint slide that is projected, key words that appear in multiple definitions may be highlighted in a different color

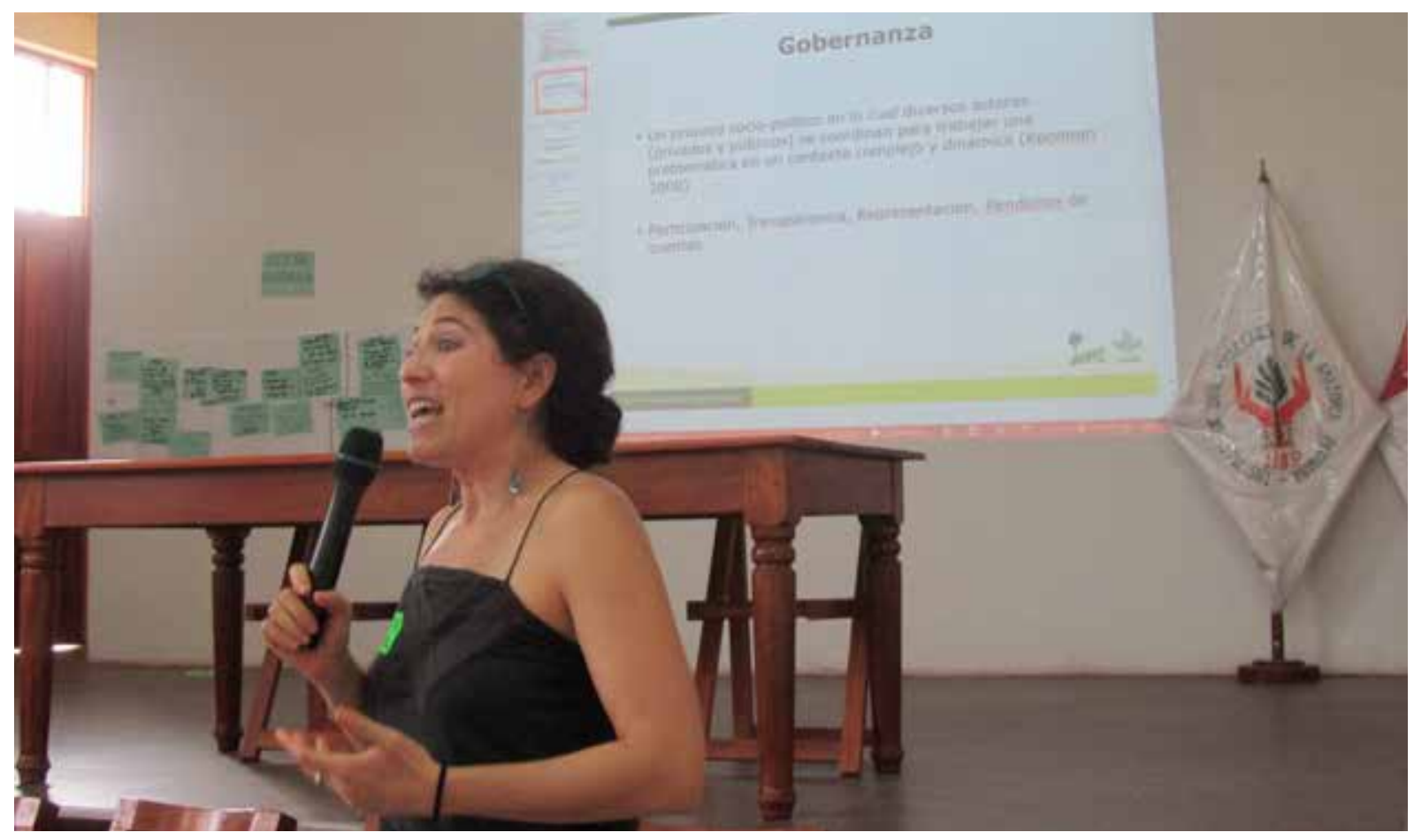




\section{Presentation on governance from} facilitation team (10 $\mathrm{min}$ )

Present a definition of governance that will be used in the workshop, recognizing commonalities and differences from participants' suggestions. One option is to cite Larson and Petkova (2011), defining governance as "who makes decisions and how decisions are made."

The concept of "good governance" is more normative, and there are a variety of opinions on what constitutes good governance. Some literature, and some actors in the development community, advance concepts like transparency and participatory decision making as pillars of good governance. This is not universally the case, however. The facilitation team might present a slide suggesting some possible "pillars" of good governance like transparency, representation, participation and accountability. At the same time, it's important to emphasize that different concepts of good governance exist, and indeed that many participants in the room may have different ideas about what constitutes good governance. Invite these suggestions, in addition to any pillars of good governance that are suggested.

Finally, explain the concept of multilevel governance - a framework for studying governance that explicitly emphasizes the importance of actors operating at different levels and representing distinct sectors. Horizontal and vertical linkages are critical determinants of land use decisions from a multilevel governance framework, and this is why actors from multiple levels and sectors have been explicitly invited to these workshops. 


\section{Monitoring and indicators of multilevel governance}

Approximate time: 1.5 hours, plenary and breakout groups

\section{Objective}

The purpose of this activity is to identify indicators of governance that can be measured objectively. These indicators should be conducive to further steps with interested participants to develop a governance monitoring tool.

\section{Methodology}

The following steps are involved in this activity:

1. Presentation by facilitation team on the concepts of "indicators" and "monitoring" (10 $\mathrm{min}$ )

A selected facilitator should explain the concepts of "indicators" and "monitoring" in the context of governance. An indicator can be described as something that is measurable and verifiable that tells us about something more fundamental or harder to measure. An individual indicator is usually an incomplete measure of the underlying concept that it is designed to assess, but multiple indicators can jointly measure a concept more completely. For example, if we are interested in "participation of actors from multiple levels and sectors" as an underlying governance concept, then the number of municipal governments that attend each meeting in a particular land use decisionmaking forum might be one indicator. Another indicator might be the number of proposals from local governments that are taken up by a higher level of government. The degree of satisfaction of civil society actors with decision - making processes, as measured by surveys, or their satisfaction with their own level of participation may be indicators of their level of participation.

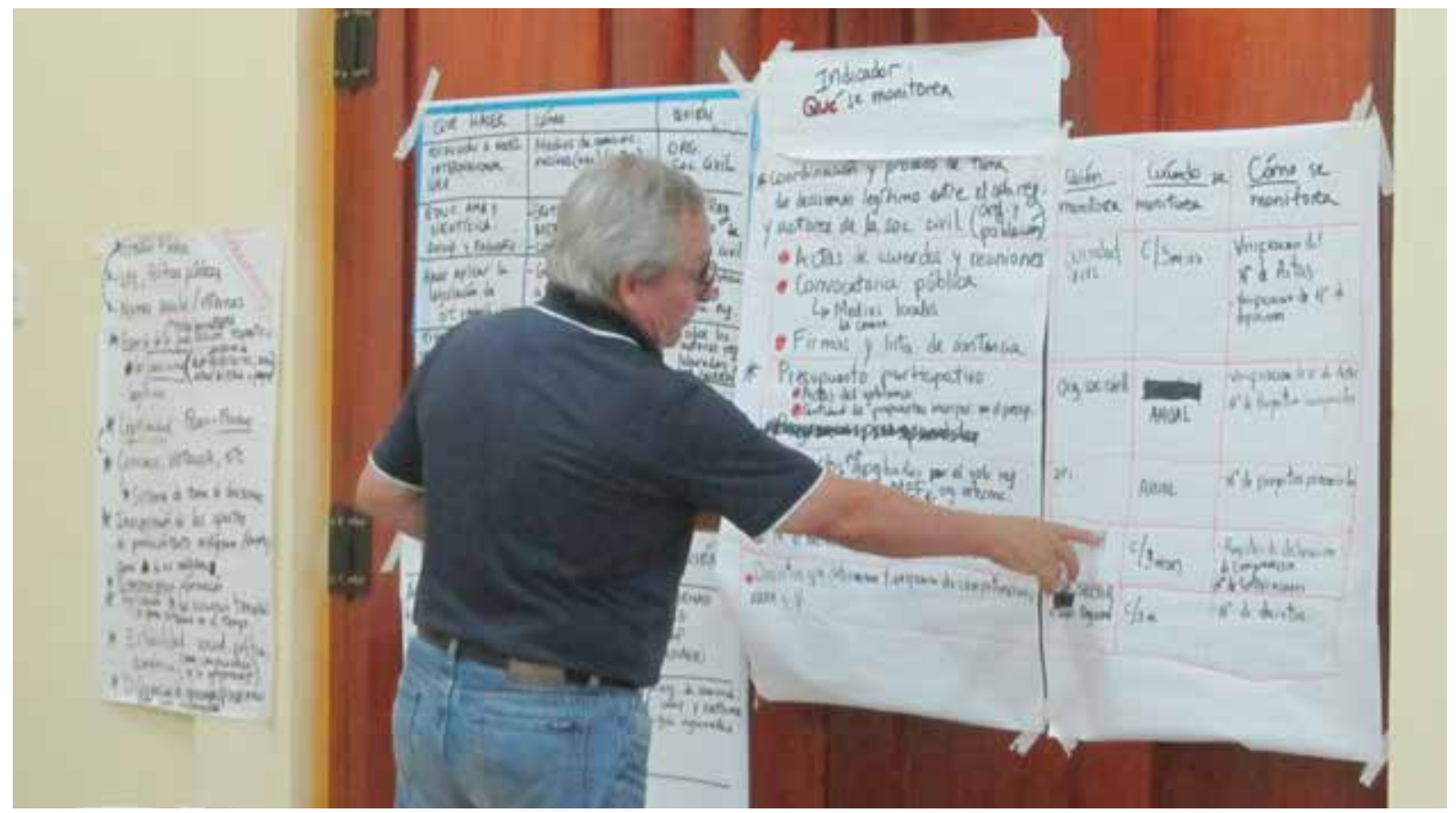


Once such indicators have been defined, questions remain of $w$ ho will monitor these indicators, how, and when. An NGO or government agency itself may monitor and measure these indicators, or some other body may be responsible for it. These are all part of the "monitoring" process, which requires clarity in these areas. A facilitator should explain all of this to the group in plenary.

\section{Development of governance indicators in groups (45 min)}

In the same groups that worked on developing strategies, activities, and steps in the previous breakout groups, facilitators should work with groups to answer the following questions.

These should be described for one or two of the activities/strategies elaborated in the previous exercise:

- What should be monitored? That is, what indicators can be measured to inform us whether we are engaged in good processes that lead towards realizing the strategy or activity that ultimately leads to the desired future scenario? What are the indicators for governance associated with the strategy or activity from the previous exercise?

- Who should monitor each indicator? Each indicator may be of a different type, and require a different monitoring strategy. Some may require simply documenting aspects of participation in meetings, others may require using secondary data such as court documents to report on frequency of sanctioning, for example, and still others may require resources to administer surveys or conduct original research. Who is best equipped, and most appropriately suited, to actually do the monitoring?

- When should these indicators be monitored? Is this a short-term, medium-term, or long-term monitoring need? How frequently does it need to be monitored?

At the end of this group work session, each breakout group should present their outputs to the broader group.

\begin{tabular}{|c|c|c|c|}
\hline Strategy & $\begin{array}{l}\text { What to monitor? } \\
\text { (indicator) }\end{array}$ & Who should monitor it? & $\begin{array}{l}\text { When should it be } \\
\text { monitored? }\end{array}$ \\
\hline \multicolumn{4}{|l|}{1} \\
\hline \multicolumn{4}{|l|}{2} \\
\hline \multicolumn{4}{|l|}{3} \\
\hline \multicolumn{4}{|l|}{4} \\
\hline 5 & & & \\
\hline
\end{tabular}

\section{Facilitation notes:}

- Each group should identify however many indicators they feel are necessary, but it's best to contain it to two activities identified in the previous exercise.

- Possible topics to suggest to encourage participants to think about indicators include participation and transparency in key forums, information flow among actors, evidence of capacity building, coordination between levels and sectors, lack of participation of certain levels of government or certain divisions, or relationships between civil society and subnational governments. 


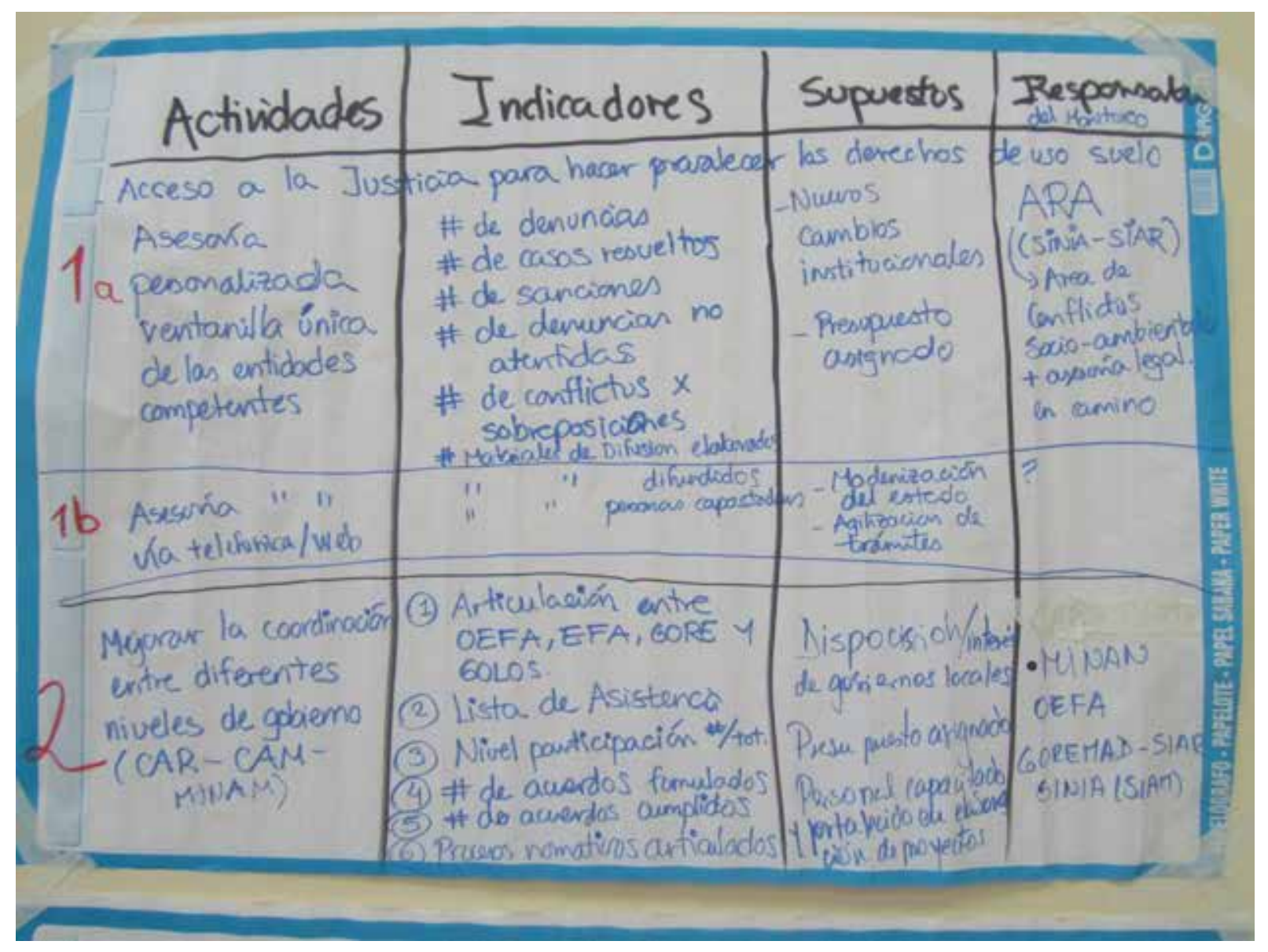

\section{Presentation and discussion of monitoring option ( $5 \mathrm{~min}$.)}

Depending on the goals of the facilitation team and their mandate, this is a good opportunity to discuss next steps. Developing indicators is a first step in a larger process of actually implementing and socializing governance monitoring. Depending on the facilitation team's resources, there are several options for next steps that can be mentioned. The most basic option is simply to share the outputs of the workshop including the indicators with the group, so that actors present can take the next steps themselves and use the workshop outputs as inputs into a governance monitoring tool or other governance monitoring activities that they wish to coordinate. A more intensive option is to solicit feedback on which participants are interested in monitoring and believe that their organization is either itself equipped to monitor governance, or may involve another organization that is. The most intensive option, if interest and resources are sufficient, is to hold another workshop focused explicitly on developing a governance monitoring tool with actors from relevant organizations. The elaboration of the methodology for such a workshop is outside the scope of this document. 


\section{Presentation of preliminary results from facilitation team study (if relevant)}

Approximate time: 30 minutes to an hour, plenary

If the facilitation team has conducted research prior to the workshop with results to share, this is an opportunity to do so, lending some context to the work done in the workshop and sharing relevant findings. This is highly dependent on timing, logistics, participant interest, and the results that the facilitation team has at its disposal. This step may not be relevant for all instances of this workshop.

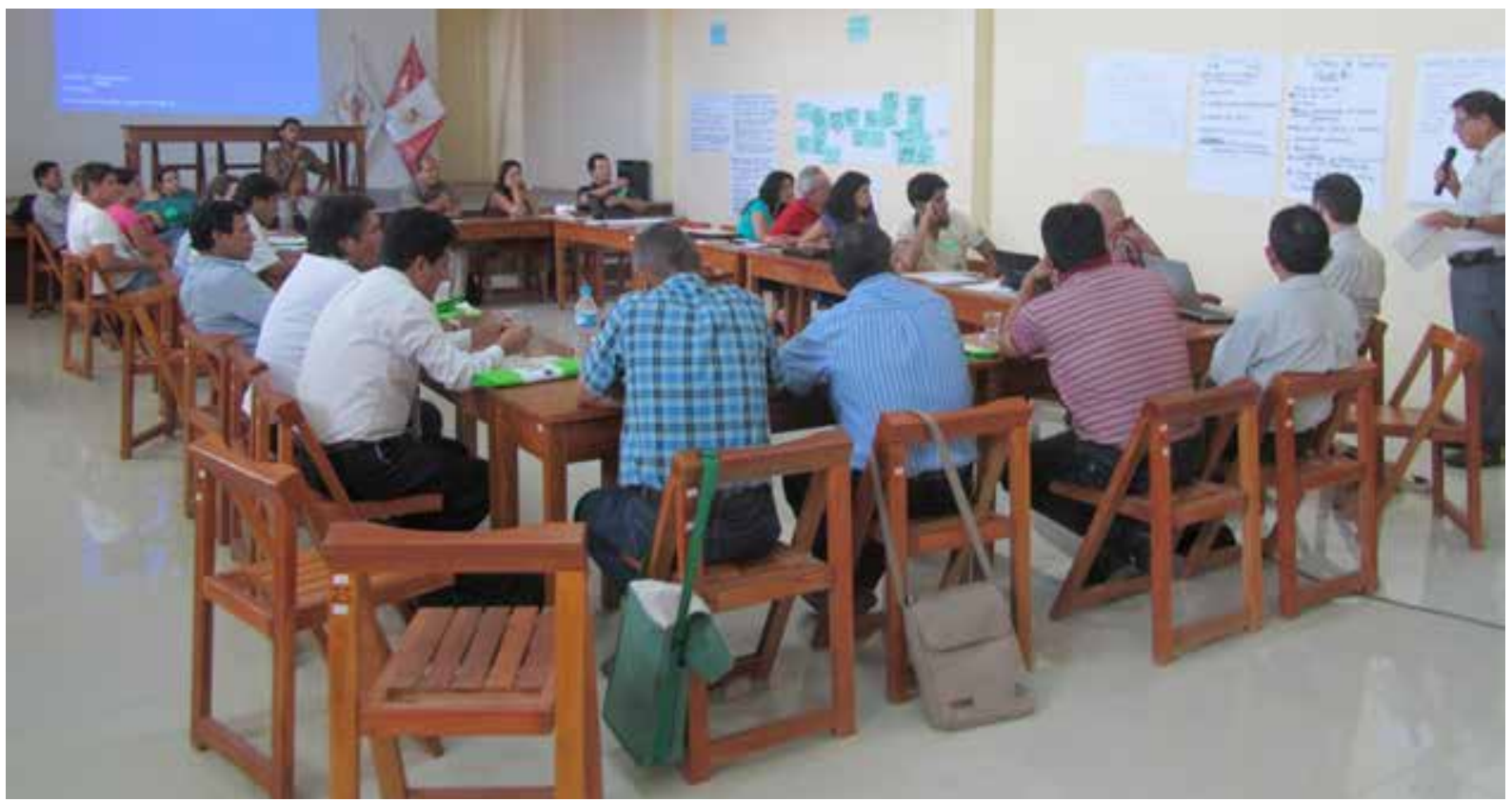




\section{End of workshop survey}

Approximate time: 30 minutes

\section{Objective}

Collect feedback on the workshop in general and the dynamics within it in particular. This can be used to improve the methodology and ensure that participants have a chance to share their thoughts and reactions with the facilitation team. The following survey represents one option:

\section{Workshop survey}

\begin{tabular}{|l|l|}
\hline Name (Optional) & \\
\hline Institution & \\
\hline
\end{tabular}

1. Please mark the degree to which you agree or disagree with the following statements about this workshop. On a scale of $1-5(1=$ strongly disagree, $5=$ strongly agree), how do you feel about the following statements?

\begin{tabular}{|c|c|c|c|c|c|}
\hline & $\begin{array}{l}\text { 1. (strongly } \\
\text { disagree) }\end{array}$ & 2. (disagree) & $\begin{array}{l}\text { 3. (neither } \\
\text { agree nor } \\
\text { disagree) }\end{array}$ & 4. (agree) & $\begin{array}{l}\text { 5. (strongly } \\
\text { agree) }\end{array}$ \\
\hline $\begin{array}{l}\text { a. This workshop involved all } \\
\text { actors that should have been } \\
\text { involved }\end{array}$ & & & & & \\
\hline $\begin{array}{l}\text { b. I had enough information to } \\
\text { contribute to discussions }\end{array}$ & & & & & \\
\hline $\begin{array}{l}\text { c. I felt comfortable expressing } \\
\text { my opinion }\end{array}$ & & & & & \\
\hline $\begin{array}{l}\text { d. The discussions were always } \\
\text { dominated by the same } \\
\text { people }\end{array}$ & & & & & \\
\hline $\begin{array}{l}\text { e. I felt that my opinion was } \\
\text { respected by the other } \\
\text { participants }\end{array}$ & & & & & \\
\hline $\begin{array}{l}\text { f. I felt more comfortable in } \\
\text { the thematic groups (the } \\
\text { first day) than in the mixed } \\
\text { groups (the second day) }\end{array}$ & & & & & \\
\hline
\end{tabular}

4. Would you like to share any other thoughts or reactions with us? 


\section{Facilitation notes for the whole workshop:}

- Designate a facilitator for each activity in advance of the workshop so everyone knows when they are supposed to do what.

- Designate a note-taker for each phase of the activity to record what is happening and discussions. These are important for the workshop report that must be returned to participants.

- Control time as strictly as possible. There are a lot of activities packed into a comparatively short time during this workshop, and long days can fatigue participants. It's important to budget time well. One technique for doing this effectively is to designate one facilitator who is not directly facilitating plenary activities as a time keeper, so as to not interrupt the flow of the facilitator who is actively engaging with participants.

- Photograph all cards and poster papers produced.

- If unexpected circumstances arise or a spontaneous unforeseen decision must be made by facilitators, then it's a good idea to take a time-out for a couple minutes and discuss the issue. This way, the facilitators can calmly discuss options and return to the group with a unified message, with all facilitators on the same page about how to deal with the unforeseen circumstance.

- Facilitate to ensure that less extroverted personalities - and especially representatives of less empowered groups - are able to speak and contribute in all activities. 


\section{REFERENCES}

Bourgoin, J and Castella JC. 2011. "PLUP

FICTION": Landscape Simulation for

Participatory Land Use Planning in Northern Lao PDR

Evans K, Velarde SJ, Prieto RP, Rao SN, Sertzen

$\mathrm{S}$, Davila K, Cronkleton P and de Jong W. 2006. Field Guide to the Future: Four Ways for Communities to Think Ahead. Nairobi:
CIFOR, ASB, World Agroforestry Centre. http://www.asb.cgiar.org/ PDFwebdocs/ Evans-et-al-2006-Field-guide-to-thefuture.pdf

Larson, AM. and Petkova E. 2011. An introduction to forest governance, people and REDD+ in Latin America: obstacles and opportunities. Forests 2(1): 86-111 


\section{ANNEX. Workshop materials}

\section{Day 1}

\section{Future scenarios of land use:}

Introduction

\begin{tabular}{|c|c|c|}
\hline TIME & ACTIVITY & MATERIALS \\
\hline 08:30-09:00 & Participant registration & $\begin{array}{l}\text { - Registration sheets } \\
\text { - Pens } \\
\text { - Nametags } \\
\text { - Markers }\end{array}$ \\
\hline 09:00-09:30 & Welcome and agenda & $\begin{array}{l}\text { - Laptop / Power Point } \\
\text { - Projector } \\
\text { - Microphone }\end{array}$ \\
\hline 09:30-10:00 & Participant introductions & $\begin{array}{l}\text { - Consider an ice breaker such as preparing sheets of paper } \\
\text { with animal names in pairs (participants must make the } \\
\text { noise or motion of the animal to find their pair) }\end{array}$ \\
\hline
\end{tabular}

Land use in the landscape

\begin{tabular}{lll}
\hline TIME & ACTIVITY & MATERIALS \\
\hline & & - Poster paper \\
10:00-11:00 & Timeline, "Journey to the Past" & - Masking tape \\
& & $\cdot$ Colored $10 \times 20 \mathrm{~cm}$ paper \\
& & - Markers \\
\hline
\end{tabular}




\section{Factors that affect land use change}

\begin{tabular}{|c|c|c|c|}
\hline TIME & ACTIVITY & & MATERIALS \\
\hline \multirow{3}{*}{ 11:15-12:30 } & \multirow{3}{*}{$\begin{array}{l}\text { Identifying } \\
\text { factors of change }\end{array}$} & Plenary & $\begin{array}{l}\text { - Laptop / Power Point } \\
\text { - Projector } \\
\text { - Microphone }\end{array}$ \\
\hline & & Individual work & $\begin{array}{l}\text { - Blank paper } \\
\text { - Pens }\end{array}$ \\
\hline & & $\begin{array}{l}\text { Breakout groups } \\
\text { and plenary }\end{array}$ & $\begin{array}{l}\text { - } \text { Poster paper } \\
\text { - } \text { Masking tape } \\
\text { - } \text { Colored paper } 10 \times 20 \mathrm{~cm} \\
\text { - } \text { Markers }\end{array}$ \\
\hline \multirow{3}{*}{ 12:30-13:00 } & \multirow{3}{*}{$\begin{array}{l}\text { Selecting factors } \\
\text { of change }\end{array}$} & Plenary & $\begin{array}{l}\text { - Laptop } \\
\text { - Projector }\end{array}$ \\
\hline & & Voting & - Stickers ( 5 yellow and 5 red) \\
\hline & & Presenting results & $\begin{array}{l}\text { - Laptop / Power Point } \\
\text { - Projector }\end{array}$ \\
\hline 13:00-14:00 & \multicolumn{2}{|c|}{ Factor determination } & - Laptop / Excel y Power Point \\
\hline
\end{tabular}

\section{Building future scenarios}

\begin{tabular}{|c|c|c|}
\hline TIME & ACTIVITY & MATERIALS \\
\hline 14:00-14:30 & Presenting the scenarios & $\begin{array}{l}\text { - Laptop } \\
\text { - Projector }\end{array}$ \\
\hline 14:30-17:30 & $\begin{array}{l}\text { Developing scenarios and drawing land } \\
\text { use change on map }\end{array}$ & $\begin{array}{l}\text { - Poster paper } \\
\text { - Map of current land use with overlaid grid: large } \\
\text { enough to draw on and copies for at least } 4 \\
\text { working groups } \\
\text { - Permanent marker to write on poster paper } \\
\text { - Colored markers to draw on map } \\
\text { - Pencils }\end{array}$ \\
\hline 17:30-18:00 & End of workshop surveys & $\begin{array}{l}\text { - Printed surveys } \\
\text { - Pens }\end{array}$ \\
\hline 18:00-18:10 & End of session & - Camera for group photo \\
\hline
\end{tabular}




and Agroforestry (CRP-FTA). This collaborative program aims to enhance the management and Forests, Trees and use of forests, agroforestry and tree genetic resources across the landscape from forests to farms. Forests, Trees and use of forstery
Agroforestry Center for Tropical Agriculture and the World Agroforestry Centre.
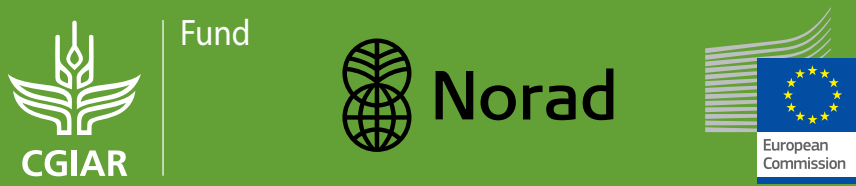